\title{
TOWARD AN INTERNATIONAL CRIMINAL PROCEDURE: DUE PROCESS ASPIRATIONS AND LIMITATIONS
}

\author{
Gregory S. Gordon*
}

\begin{abstract}
"Perfection is impossible; like other human institutions criminal proceedings must be a compromise."
\end{abstract}

Judge Learned Hand ${ }^{1}$

"It is by compromise that human rights have been abandoned."

Senator Charles Sumner ${ }^{2}$

\section{INTRODUCTION}

The breathtaking growth of international criminal law over the past decade has resulted in the prosecution of Balkan and Rwandan mass murderers, the development of a substantial body of atrocity law jurisprudence and the creation of a permanent International Criminal Court with jurisdiction over genocide, crimes against humanity, and war crimes. The growth of international criminal procedure, unfortunately, has not kept pace. Among its shortcomings, critics have pointed to lengthy pre-trial detention without a real possibility of provisional release, the use of affidavits and transcripts instead of live witnesses at trial, the absence of juries, and the right of prosecutorial appeal. Given the substantive law advances, why is international criminal procedure lagging behind? Why has it failed to achieve the level of due process offered by the most rights-protective countries, such as the United States? Are there long-term structural limits to the growth of international criminal procedure? Neither the framers of the new international tribunals nor the academic commentators have attempted to answer these questions in a systematic or comprehensive way.

This Article will attempt to do so. It begins with the premise that, in the fertile human rights soil of international criminal law, ${ }^{3}$ a procedural scheme nourished on

\footnotetext{
* (C) 2006. Assistant Professor, University of North Dakota School of Law. The author is indebted to Professors Jonathan Bush, Ronald F. Wright, Jr., Joseph Rikhof, Kirsten Dauphinais, Jason Kilborn, Robert Pfeffer, Dr. Rhonda Schwartz, Department of Justice Senior Trial Attorneys Joseph Gaeta and Melissa Schraibman, and the author's Research Assistant, Christopher Rausch. This article would not have been possible without the support and love of the author's wonderful wife and children.

${ }^{1}$ In re Fried, 161 F.2d 453, 465 (2d Cir. 1947).

${ }^{2}$ Worldofquotes.com, http://www.worldofquotes.com/topic/Compromise/index.html (last visited Sept. 4, 2006).

${ }^{3}$ Since they are meant to redress grave violations of human rights, the "extension to international criminal proceedings of international human rights provisions of due process," SALVATORE ZAPPALÀ,
} 
fundamental notions of due process has at least taken root. ${ }^{4}$ Its growth has been slow but steady. From the bare-bones privileges afforded defendants at the International Military Tribunal at Nuremberg, to the more fleshed-out protections of the ad hoc Yugoslav and Rwanda tribunals, to the recent refinements of the International Criminal Court, the rights of the accused in the international criminal dock have most certainly expanded. ${ }^{5}$ As noted above, however, they have only gone so far. ${ }^{6}$

To understand why, it is instructive to consider the criminal procedure framework of sovereign countries, such as the United States. These entities possess legal and physical characteristics conducive to relatively uniform and effective enforcement of a criminal defendant's due process rights. For example, nation-states rely on their own internal enforcement mechanisms to insure compliance with policy directives and rules. ${ }^{7}$ The latter, for their part, are established pursuant to the overarching norms of a homogenous legal paradigm (for example, a common law adversarial system or a civil

Human Rights In INTERNATIONAL CRIMINAL PROCEEDINGS 7 (2003), can be seen as a logical and salutary result. In addition to lending the proceedings moral and institutional coherence, such an extension helps spare war-torn populations the ordeal of domestic criminal justice wielded as an instrument of vengeance. $I d$. at 6 . At the same time, respect for due process may serve as a model and inspiration for those populations as they attempt, in the aftermath of international criminal prosecution, to reconstruct what is left of their own ravaged justice infrastructure. See Neil J. Kritz, Coming to Terms with Atrocities: A Review of Accountability Mechanisms for Mass Violations of Human Rights, 59-AUT LCPR 127, 147 (1996). With respect to States, whose cooperation is essential to the success of international tribunals, the due process regime permits them to execute the requests of the tribunals while complying with their own internally and externally imposed human rights obligations. Zappalà, supra, at 6 .

4 See generally Christian Defrancia, Due Process in International Criminal Courts: Why Procedure Matters, 87 VA. L. REV. 1381 (2001). See also Göran Sluiter, International Criminal Proceedings and the Protection of Human Rights, 37 NEW ENG. L. REV. 935, 936 (2003) ('Human rights 'enter' the legal framework of the Tribunals in a number of ways. The most direct application of human rights law constitutes the rights explicitly set out in the Statutes and the Rules of Procedure and Evidence.").

5 See Defrancia, supra note 4, at 1381. See also Michele Caianiello \& Giulio Illuminati, From the International Criminal Tribunal for the Former Yugoslavia to the International Criminal Court, 26 N.C.J. INT'L L. \& COM. REG. 407 (2001); Patricia M. Wald, Trying War Crimes in International Courts, 31 INT'L J. LEGAL INFO. 278 (2003) (noting that the recent ICC rules of procedure represent a "significant improvement" over its predecessors).

6 The criminal procedure problems identified above -- lengthy pre-trial detention without a real possibility of provisional release, the use of affidavits and transcripts instead of live witnesses at trial, the absence of juries, and the right of prosecutorial appeal -- as well as others identified infra, are not explicitly enjoined by "international due process," an accretion of norms derived from international and regional treaties as well as the jurisprudence of international courts. See M. CHERIF BASSIOUNI, InTRODUCTION TO INTERNATIONAL CRIMINAL LAW 586-87 (2003). In a magisterial undertaking, Professor Bassiouni has set out these individual norms and their sources. Id. at 591-626. Although these norms "reflect the adversary/accusatorial model of criminal justice," $i d$., and represent significant progress in the evolution of international due process, they do not reach the level of protection found in the most rights-protective systems, such as the United States. See Shane B. Kelbley, Reason Without Borders: How Transnational Values Cannot Be Contained, 28 FordHAM INT'L L. J. 1595, 1628 (2005) (“'With respect to criminal procedure] the United States is . . one of the most rights-protective Nations in the world."). The advanced protections in those systems, particularly the United States, will be the normative point of repair for this Article. They will serve as a conceptual reference to illustrate why the growth of international due process has been cabined by the peculiar characteristics of international criminal adjudication.

7 See Shabtai Rosenne, Poor Drafting and Imperfect Organization: Flaws to Overcome in the Rome Statute, 41 VA. J. INT'L L. 164, 181 (2000). 
law inquisitorial tradition). ${ }^{8}$ And while these entities deal with prosecuting large-scale, serious crimes, they are rarely, if ever, called upon to confront the kind of widespread mass murder and extreme violence that rises to the level of genocide, crimes against humanity or war crimes.

International criminal tribunals and courts are not so fortunate. ${ }^{9}$ For the most part, they depend on external agents (i.e., States) to search for and collect evidence, apprehend suspects, and surrender them to the tribunals. ${ }^{10}$ There is only so much control they can wield over States in this regard. In some cases, where tribunal and State might otherwise be in accord, national security concerns may hinder State cooperation. ${ }^{11}$ Moreover, even if tribunals were self-sufficient with respect to enforcement, they are forced to compromise internally regarding procedural matters. This is so because each international tribunal must harmonize the imperatives of two different, often conflicting legal systems - the common law and the civil law. ${ }^{12}$ Certain due process rights are unfortunately sacrificed on the altar of this artificial union. ${ }^{13}$ Finally, international criminal tribunals are not established to handle garden-variety crime. To the contrary, they exist to prosecute the most heinous crimes ever committed - genocide, crimes against humanity and war crimes. ${ }^{14}$ When weighed against the gravity of these horrific offenses, the otherwise compelling mandate to enforce criminal procedure protections may lose some of its urgency.

In the context of these considerations, this Article will attempt a comprehensive, structural explanation of the competing forces at work behind the development of due

\footnotetext{
${ }^{8}$ See id.

9 See Bassiouni, supra note 6, at 589 ("International adjudication also presents unique problems that are unknown to national legal systems in that the former relies on the voluntary cooperation of states, while the latter benefits from the vertical authoritative process that exists in domestic legal orders.").

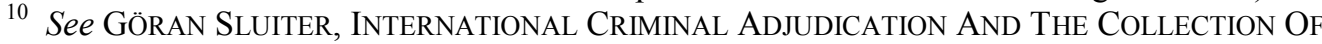
EVIDENCE: OBLIGATION OF STATES 6-7 (2002).

${ }^{11}$ See generally Herwig Roggemann \& Petar ŠArČEvić, NATIONAL SeCurity AND INTERNATIONAL CRIMINAL JUSTICE (2002).

12 See Christoph Safferling, TOWARD An InTERnATIONAL CRIMINAL PROCEDURE 1-2 (2001) (referring to the "wide gap between the Anglo-American and the Continental traditions of criminal procedure.").

${ }^{13}$ See Lee A. Casey, The Case Against the International Criminal Court, 25 FordHAM INT'L L. J. 840, 868 (2002) ("Although each of these systems [the common law and the civil law] works well enough in its own context, and on its own terms, they do not mix well together."); Robert Christensen, Getting to Peace by Reconciling Notions of Justice: The Importance of Considering Discrepancies between the Civil and Common Legal Systems in the Formation of the International Criminal Court, 6 UCLA INT'L L. \& ForEIGN AFF. 391 (2002) (The distinction is especially apparent when civil and common law traditions are contrasted because "between [those] two systems, cultural, economic, and political factors have created individuals with attitudes and very distinct points of view about the legal norms that should regulate our conduct.").

14 See GEERT-JAN ALEXANDER KNOOPS, AN INTRODUCTION TO THE LAW OF INTERNATIONAL CRIMINAL TRIBUNALS, A COMPARATIVE STUDY 21-22 (2003); Theresa Marie Clark, Transplant Justice?: The Efficacy of a Purely Common Law Concept in the International Criminal Forum, 9 BuFF. HUM. RTS. L. REV. 75, 109 (2003) ("The international community established the ICTY and ICTR primarily to hold accountable those guilty of the most heinous crimes known to humankind."); Erin L. Borg, Sharing the Blame for September Eleventh: The Case for a New Law to Regulate the Activities of American Corporations Abroad, 20 ARIZ. J. INT'L. \& COMP. L. 607, 636 (2003) ("The ICC has jurisdiction over the world's criminals that commit the most heinous of crimes, such as genocide, war crimes, and crimes against humanity.").
} 
process in international criminal procedure. ${ }^{15}$ On one hand, Part II will trace the growth of international criminal procedure from Nuremberg to the International Criminal Court. It will show that the advances in extending due process protections parallel the growth of human rights law globally and, to a certain extent, criminal procedure in the United States. On the other hand, Part III will explore the forces checking the due process expansion of international criminal procedure. It will focus on three separate phenomena as contributing to this restriction: (1) fragmentation of enforcement; (2) integration of conflicting legal systems; and (3) gravity of the crimes involved. The interaction of these three restricting phenomena will then be analyzed. Finally, Part IV will examine the impact these forces may have on the future development of due process in international criminal procedure. In the end, the Article will conclude that any future growth of due process will hinge on efforts to achieve greater degrees of structural globalization, procedural hybridization, and transnational public awareness.

\section{THE DEVELOPMENT OF DUE PROCESS IN INTERNATIONAL CRIMINAL PROCEDURE}

\section{A. The International Military Tribunal at Nuremberg}

The genesis of modern international criminal justice traces back to the end of World War II with the establishment of the International Military Tribunal at Nuremberg ${ }^{16}$ ("IMT"). ${ }^{17}$ After the Allied victory in 1945, France, the United Kingdom, the United States, and the Soviet Union met in London and established an agreement (commonly referred to as the "London Agreement") for the creation of the IMT. ${ }^{18}$ On

\footnotetext{
15 In general, experts have classified justice systems into three separate categories: domestic legal justice, international criminal justice, and "hybrid" criminal justice, a term used to describe newly emerging forms of mixed national-international criminal adjudication as found in, for example, the Sierra Leone and proposed Cambodia tribunals. See, e.g., Antonio CASSESE, InTERnAtional Criminal LAW 455-56 (2003). As specific domestic structures are grafted onto "hybrid" criminal procedure, Cassese, id. at 45657, this Article will not include analysis of them within its scope. For purposes of this Article, the term "international criminal procedure" is meant to encompass the rules developed by the following truly international courts (i.e., in addition to having multinational traits, not being moored to one specific domestic tradition): the International Military Tribunal at Nuremberg (and, given its great similarity to the Nuremberg Tribunal, the International Military Tribunal for the Far East at Tokyo), the International Criminal Tribunal for the Former Yugoslavia, the International Criminal Tribunal for Rwanda, and the International Criminal Court.

${ }^{16}$ An equally important and contemporaneous development was the establishment of the International Military Tribunal for the Far East (IMTFE) or Tokyo Tribunal for the prosecution of Imperial Japanese war criminals in connection with World War II-related offenses. Section III of the Charter of this Tribunal dealt with the issue of fair trial. Since "the provisions of this section were similar to those contained in the Charter of the Nuremberg Tribunal," Zappalà, supra note 3, at 20 (2003), this Article will not undertake a separate analysis of the criminal procedure elements of the IMTFE. See also Cassese, supra note 15, at 332 ("By and large, the Tokyo Charter was modeled on the Nuremberg Charter.").

17 See Diane F. Orentlicher, International Criminal Law and the Cambodian Killing Fields, 3 ILSA J. INT'L \& COMP. L. 705 (noting that with Nuremberg begins the recognition that certain crimes are of universal concern and become the world's responsibility); Peggy E. Rancilio, From Nuremberg to Rome: Establishing an International Criminal Court and the Need for U.S. Participation, 78 U. DET. MERCY L. REV. 299, 300 (2001); Caianiello \& Illuminati, supra note 5, at 413.

18 Charter of the International Military Tribunal Annexed to the London Agreement, Aug. 8, 1945 [hereinafter Nuremberg Charter], reprinted in REPORT OF ROBERT H. JACKSON, UNITED STATES
} 
August 8, 1945, the Charter of the IMT ("Nuremberg Charter" - attached to the London Agreement) was signed. ${ }^{19}$ The Charter mandated that each of the four victorious allied powers appoint one judge and one of four chief prosecutors. ${ }^{20}$ Pursuant to Articles 13 and 14 of the Charter, the Tribunal was to draft rules of procedure for review and approval by a committee of the chief prosecutors. ${ }^{21}$ The approved Rules of Procedure were then included in the Charter. ${ }^{22}$

The Charter and the Rules of Procedure yielded a skeletal set of due process guarantees for the Nuremberg defendants:

(1) At a reasonable time before trial, the right to be furnished with the indictment, and all supporting documents lodged with the indictment, as well as the Charter, an explanation of the right to counsel (listed below), and a list of defense counsel, in a language which the accused understands;

(2) During any preliminary examination or trial, the right of the accused to give any explanation relevant to the charges made against him;

The right to have the proceedings conducted in or translated into a language the accused understands;

The right of the accused to conduct his own defense or have assistance of counsel; and

The right, through himself or through his counsel, to present evidence at trial in support of his defense and to cross-examine any witness called by the prosecution. ${ }^{23}$

Representative To The International Conference On Military Trials 420-29 (1949). See also Rancilio, supra note 17, at 300; Jonathan A. Bush, Lex Americana: Constitutional Due Process and the Nuremberg Defendants, 45 ST. LOUIS U. L.J. 515, 523 (2001).

19 Id. The London Agreement stated in Article 2 that "The constitution, jurisdiction and functions of the International Military Tribunal shall be those set in the Charter annexed to this Agreement, which Charter shall form an integral part of this Agreement." London Agreement of August 8, 1945 at http://www.yale.edu/lawweb/avalon/itm/proc/imtchart.htm.

${ }^{20}$ Michael P. Scharf, BALKAN JUSTICE: THE STORY BEHIND THE FIRST INTERNATIONAL WAR CRIMES TRIAL SINCE NUREMBERG 10 (1997).

21 Id. at 7.

22 See Howard S. Levie, War Crimes in the Persian Gulf, 1996 ST. LOUIS-WARSAW TRANSATLANTIC L.J. 153, 157 (1996).

23 See Nuremberg Charter, supra note 18, art. 16; Nuremberg Trial Proceedings Vol. 1, Rules of Procedure at http://www.yale.edu.lawweb/avalon/imt/proc/imtrules.htm. See also Rancilio, supra note 17, at 303. Other provisions in the Charter, which imposed certain duties on the IMT, had the indirect effect of protecting defendants' due process rights. For example, pursuant to Article 17, the IMT was accorded powers such as the authority to summon witnesses, to order the production of documents or other evidentiary materials, or to appoint court officers for the purpose of collecting evidence. Nuremberg Charter, supra note 18, art. 17. Professor Zappalà points out, however, that these powers may not have contributed toward a fair trial as they were not exercised in favor of the defense. See Zappalà, supra note 3, at $19-20$. 
This nascent form of international criminal procedure has been criticized as fundamentally unfair. ${ }^{24}$ At least part of the criticism stems from the Tribunal's attempts to incorporate civil law features into the proceedings. "The general historical consensus accepts the thesis that the Nuremberg Charter, its resulting rules of procedure and evidence, and those of the courts that followed in its wake, were the result of a compromise 'blending and balancing elements of the Continental European inquisitorial system and the Anglo-American adversarial system.",25 This would have tended to dilute due process protections because "it is generally recognized that the adversarial system is more suitable when in comes to offering protection to the rights of the accused." 26 By and large, under the civil law "inquisitorial" system, most of the documentary and testimonial evidence is presented to an examining magistrate who assembles it in a dossier. ${ }^{27}$ Copies of the magistrate's dossier are provided to the defendant and to the court prior to trial. ${ }^{28}$ The court, either on its own motion or at the request of one of the parties, can question witnesses directly. Moreover, in contrast with the adversarial system, cross-examination by opposing counsel is rare. ${ }^{29}$ As Professor Salvatore Zappalà explains:

Generally speaking it may be recalled that these models historically reflect different conceptions of 'judicial truth.' The inquisitorial perspective generally considers that the objective of the criminal process is ascertaining the truth; this is and should be the overriding concern of the rules of criminal procedure. These rules must enable the 'inquisitor' to extract the truth from the suspect. On the other hand, from an accusatorial viewpoint the process per se is what really matters. The establishment of historical truth cannot be ensured other than through respect for procedural rules, which constitute the method for reaching 'judicial truth.' In the end, this differentiation reflects two opposing epistemological beliefs: while for the inquisitorial paradigm there is an objective truth that the 'inquisitor' must ascertain, for the

24 See, e.g., Jose E. Alvarez, Rush to Closure: Lessons of the Tadic Judgment, 96 MICH. L. REV. 2031, 2037 (1998) ("Prominent critics complain that the Nuremberg and Tokyo processes were tainted by "victor's justice," including procedures and verdicts that were unfair to the defendants."); Bassiouni, supra note 6, at 408 ("By contemporary standards, however, the procedural rights afforded the defendants were quite limited."); KELLY DAWN ASKIN, WAR CRIMES AGAINST WOMEN: PROSECUTION IN INTERNATIONAL WAR CRIMES TRIBUNALS 98-99 (1997) (faulting Nuremberg for inadequate procedural safeguards).

25 Evan J. Wallach, The Procedural and Evidentiary Rules of the Post-World War II War Crimes Trials: Did They Provide an Outline for International Legal Procedure?, 37 COLUM. J. TRANSNAT'L L. 851, 854 (1999) (quoting Virginia Morris \& Michael Scharf, AN INSIDER's GUIDE TO THE INTERNATIONAL CRIMINAL TRIBUNAL FOR THE Former YugoslaVia 7-8 (1995)). See also Caianiello \& Illuminati, supra note 5, at 414 ("The Nuremberg Charter and Rules of Procedure tried to blend and balance elements of the Continental European system, which is primarily inquisitorial, and the Anglo-American adversarial system.").

26 Zappalà, supra note 3, at 16.

27 Scharf, supra note 20, at 6.

28 Id. at 6-7.

${ }^{29}$ Id. 
accusatorial approach the truth is the natural and logical result of a pre-determined process. ${ }^{30}$

According to Professor Antonio Cassese, the upshot of this is that the Continental system is "more geared toward the protection of the interests of society..." (i.e., providing for expeditious hearings and preventing delays). ${ }^{31}$ The Anglo-American approach, on the other hand, is "bent on enhancing the rights of the accused and more generally on ensuring respect for the fundamentals of 'due process.",32

In the specific case of the IMT, the inquisitorial influence meant that, instead of live testimony subject to cross-examination, a large number of affidavits and depositions were admitted into evidence, preventing the accused from confronting witnesses in open court. $^{33}$ Moreover, the proceedings have been described as "trial by ambush" - i.e., proceedings overly expedited (in the spirit of the Continental system) ${ }^{34}$ given the enormity of the charges, the volume of the evidence and the novelty of the procedure and rules for the defense attorneys. ${ }^{35}$

Other civil law influences, not necessarily written into the Charter, contributed toward eroding the rights of the accused. ${ }^{36}$ In the first place, when the prosecution did offer live testimony, civil law-trained defense counsel failed to interpose objections or conduct effective cross-examination. ${ }^{37}$ Furthermore, the conditions and resources available for the defense to undertake independent investigations, an essential component of protecting the defendant's rights in the adversarial model, were not adequate. ${ }^{38}$ Even if they were, most of the civil law defense attorneys, accustomed as they were to a magistrate taking the investigative laboring oar, could not grasp the importance of

30 Zappalà, supra note 3 , at 16 .

31 Cassese, supra note 15, at 383 (emphasis in original).

32 Id. (emphasis in original).

33 See Zappalà, supra note 3, at 18; Alvarez, supra note 24, at 2037. See also Michael P. Scharf, Have We Really Learned the Lessons of Nuremberg, 149 MIL. L. REV. 65, 69 (1995) ("The Nuremberg Tribunal has been severely criticized for allowing the prosecutors to introduce ex parte affidavits against the accused over the objections of their attorneys. Such affidavits, it has been argued, seriously undermined the defendant's right to confront witnesses against him.").

34 See Cassese, supra note 15 , at 383 . On the flip side, there was certainly no deprivation of the right to a speedy trial.

35 See Alvarez, supra note 24, at 2037. On the other hand, certain civil law Charter provisions arguably strengthened the rights of the accused. For example, contrary to the prevailing Anglo-American practice, the Charter permitted defendants to make unsworn statements on their own behalf at the end of the trial. See Caianiello \& Illuminati, supra note 5, at 415. Similarly, the Charter required, inconsistent with standard common law rules, that the indictment detail the specific charges against the defendants and include any supporting documents. Id.

36 See Zappalà, supra note 3, at 21 ("Two issues, however, must be distinguished: on the one hand, the question of the fairness of the rules of procedure in abstract; on the other, their concrete application which allegedly led to the substantial unfairness of the trials. It has been argued that the Rules were theoretically adequate to give the defendants a fair trial and that it was in fact their application that was unfair.").

37 See Alvarez, supra note 24, at 2037.

38 Id. 
conducting such investigations. ${ }^{39}$ Finally, abhorrent to common law notions of due process but permissible in the civil law tradition, the IMT allowed for in absentia trials. ${ }^{40}$

These were not the only shortcomings. In the first place, there were absolutely no due process safeguards for suspects during the investigation phase of the proceedings. ${ }^{41}$ Protections were lacking at all other stages as well. For example, there was no express rule on the presumption of innocence ${ }^{42}$ or the duty of the prosecutor to disclose exculpatory evidence to the accused. ${ }^{43}$ There was no right to remain silent, or a right to provisional release. ${ }^{44}$ There was no double jeopardy protection. ${ }^{45}$ More importantly, there was no right to appeal. ${ }^{46}$

Apart from the inquisitorial influence, why were such fundamental safeguards

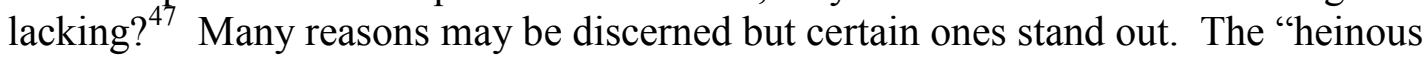
character" of the crimes "meant that an in-depth and thorough reflection on the protection of the rights of persons accused of crimes against humanity, crimes against peace, and war crimes was not easy." 48 Another equally apparent explanation is "the haste with which the victors set up the Tribunals after having considered various options for dealing with such novel, widespread, and large-scale crimes, allegedly committed not only by servicemen in the field, but also by military and political leaders, as well as civilians (such as industrialists, etc.).",49

39 Id.

40 For example, Martin Bormann, Nazi Party Chancellery Head Secretary and Private Secretary to Adolph Hitler, was tried in absentia and found guilty. See Bush, supra note 18, at 536.

41 See Zappalà, supra note 3, at 45.

42 See Zappalà, $i d$. note 3 , at 21 . However, in practice, a presumption of innocence and beyond-areasonable-doubt burden of proof for the prosecution obtained. Although this is not spelled out in the Charter, it is reflected in the IMT's written decisions. See, e.g. Hjalmar Schacht Decision [hereinafter "Schacht Decision"], IMT Judgment, Oct. 1, 1946 reprinted in THE TRIAL OF GERMAN MAJOR WAR Criminals: ProceEdings Of The InTERnAtional Military TRIBUnAl SitTing At NuREMBERG GERMANY 551-55 (1946) ("The case against Schacht therefore depends on the inference that Schacht did in fact know of the Nazi aggressive plans. . . The Tribunal has considered the whole of this evidence with great care, and comes to the conclusion that this necessary inference has not been established 'beyond a reasonable doubt." Id. at 554-55.

43 See Zappalà, supra note 3 , at 21.

44 See id.

45 Indeed, the Nuremberg Charter expressly stated that any person convicted by the IMT could be charged subsequently by a national court for any crime other than membership in a criminal organization. Nuremberg Charter, supra note 18, art. 11. In fact, three Nuremberg defendants who were acquitted -Hjalmar Schacht, Hans Fritzsche, and Franz von Papen -- were subsequently prosecuted in German courts. See Kevin R. Chaney, Pitfalls and Imperatives: Applying the Lessons of Nuremberg to the Yugoslav War Crimes Trials, 14 DICK. J. INT’L L. 58, (1995).

${ }^{46}$ Louise Arbour, Progress and Challenges in International Criminal Justice, 21 Fordham Int'1 L. J. 531, 539 (1997) (“The Nuremberg Tribunal could and did impose the death penalty, and there was no right of appeal.").

47 It should be noted that perhaps the most frequent criticism lodged against the IMT was that it violated the principle of nullum crimen, nulla poena sine praevia lege, which roughly translates to "no crime or punishment for conduct is allowed without the previous existence of a law prohibiting that conduct and providing for that punishment." See Cassese, supra note 15, at 70-72.

48 See Zappalà, supra note 3, at 21-22.

49 Id. at 21. 
Perhaps less obvious to contemporary students of criminal justice is the fact that many of the procedural protections we take for granted today were simply not available in 1945. In the first place, the birth of the modern human rights movement, which spawned the due process guarantees to which Western democracies are now so accustomed, dates back only to the years after the Second World War ended. ${ }^{50}$ Thus, the Nuremberg Charter would not have incorporated them as a normative point of repair. Professor Zappalà points out that "most international standards relating to the protection of fundamental rights in the administration of criminal justice had not yet been the object of international law-making."51

Only in 1948 does an incipient form of international human rights law begin to emerge. On December 8 of that year, the General Assembly of the young United Nations agreed on a Resolution that is known as the Universal Declaration of Human Rights (UDHR). ${ }^{52}$ Within this pioneering document, Articles 9 (right not to be exposed to arbitrary arrest), ${ }^{53} 10$ (right to a fair and public hearing by an independent and impartial tribunal) ${ }^{54}$ and 11 (right to be presumed innocent until proven guilty and prohibition against ex post facto laws) ${ }^{55}$ limn the traits of a nascent, but non-binding, criminal procedure. 56 The International Covenant on Civil and Political Rights ("ICCPR"), which gave teeth to and expanded the UDHR due process protections, was not even signed until nearly twenty years later, in $1966 .^{57}$ The ICCPR did not enter into force for another ten years. 58

50 See David Weissbrodt, An Introduction to the Sources of International Human Rights Law, C399 ALI-ABA 1, 7-9 (1989) ("[M]ost observers regard the formation of the United Nations and the promulgation of the Universal Declaration of Human Rights as the beginning of the modern struggle to protect human rights. . . Modern international human rights law arose in the 1940s."). See also Jeffrey A. Brauch, Why a Journal of International Law at Regent University School of Law, 1 REGENT J. INT'L. L. 1, 2 (2003) ("Although the human rights movement has historical antecedents, the current movement took shape largely in response to atrocities committed just prior to and during World War II.").

51 Zappalà, supra note 3 , at 46.

${ }^{52}$ Universal Declaration of Human Rights, adopted Dec. 10, 1948, G.A. Res. 217A(III), UN Doc. A/810, at 71(1948).

${ }^{5}$ Id. art. 9.

54 Id. art. 10.

55 Id. art. 11.

56 See Safferling, supra note 12, at 22 ("This document [the UDHR] has never gained binding effect on the Member States of the UN.").

57 International Covenant on Civil and Political Rights, Dec. 16, 1966, G.A. Res. 2200A (XXI), 21 U.N.GAOR Supp. (No. 16) at 52, U.N. Doc. A-6316 (1966), entered into force Mar. 23, 1976 [hereinafter ICCPR]. ICCPR Articles 9 and 10 prohibit arbitrary arrest, detention, or exile. Articles 14 and 15 provide for the presumption of innocence, the right to a fair trial, and the prohibition of ex post facto laws. The key Article on the rights of persons accused in criminal proceedings is Article 14. This Article, much more detailed than the corresponding provisions of the UDHR, details a panoply of minimum fair trial guarantees for the accused in Paragraph 3 of Article 14. These include: the right to be informed of the charges, the right to have adequate time and facilities for the preparation of the defense, the right to be tried without undue delay, the right to legal assistance, the right to examine witnesses and obtain their attendance, the right to have an interpreter, and the privilege against self-incrimination. See Brenda Sue Thornton, The New International Jurisprudence on the Right to Privacy: A Head-On Collision with Bowers $v$. Hardwick, 58 ALB. L. REV. 725, 734 n.64 (1995).

58 Thornton, supra note 57, at 734 . 
These gradual international developments were mirrored by comparable regional efforts during the same time period. Among these is the European Convention on Human Rights (EHCR), which entered into force in 1950, ${ }^{59}$ and contains criminal procedure fairness guarantees, primarily in Articles 6 (prohibiting ex post facto laws) and 7 (providing for a fair trial). ${ }^{60}$ In the Americas, Article 26 of the American Declaration of Rights and Duties of Man (1948) ${ }^{61}$ and Article 8 of the American Convention on Human Rights (1969) ${ }^{62}$ also embody comparable fair trial protections. Finally, the African Charter on Human and Peoples' Rights (1981) ${ }^{63}$ ensures fair trial rights in its Article 7.

In the United States, the pantheon of landmark Warren Court rulings that ushered in the criminal procedure "due process revolution of the 1960 's," 64 post-dated the Nuremberg Charter by nearly two decades. These cases, and the principles they enshrine, now seemingly ingrained in our judicial fabric, were simply not part of the criminal procedure lexicon of the Nuremberg architects. ${ }^{65}$ These ground-breaking precedents include: Wong-Sun v. United States ${ }^{66}$ (evidence that is "the fruit of the poisonous tree" must be excluded); Gideon v. Wainwright ${ }^{67}$ (indigent defendant has right to be provided at trial with counsel at state's expense) ${ }^{68}$; Brady v. Maryland ${ }^{69}$ (prosecutor has duty to disclose exculpatory evidence to the defense); Massiah v. United States ${ }^{70}$ (restrictions on post-indictment interrogations); Miranda v. Arizona ${ }^{71}$ (certain warnings required before police may interrogate a suspect in custody); Chapman v. California ${ }^{72}$ (infraction of basic

591950 European Convention on Human Rights and Fundamental Freedoms, opened for signature Nov. 4, 1950, 213 U.N.T.S. 222, E.T.S. No. 5, art. 3 (entered into force Sept. 3, 1953). This Convention is enforced through the issuance of legally binding decisions through the European Court of Human Rights the Convention's "functioning supervisory machinery." Safferling, supra note 12, at 23.

${ }^{60}$ Safferling, supra note 12, at 23.

61 American Declaration of Rights and Duties of Man, signed May 2, 1948, O.A.S. Off. Rec. OEA/ser. L./V/II. 23. Doc. 21, rev. 6 (English 1979).

62 American Convention on Human Rights, signed Nov. 22, 1969, entered into force July 18, 1978, O.A.S. Off. Rec. OEA/ser. L./V/II. 23. Doc. 21, rev. 2 (English 1979).

63 African [Banjul] Charter on Human and Peoples' Rights, adopted June 27, 1981, OAU Doc. CAB/LEG/67/3 rev. 5, 21 I.L.M. 58 (1982), entered into force Oct. 21, 1986.

${ }^{64}$ Bush, supra note 18, at 515. Zappalà, supra note 3, 46 n.50 ("In this respect it has also been clarified that in 1945, even the US Supreme Court had not yet thoroughly developed its jurisprudence on fair trial safeguards.").

65 And this is significant, given the disproportionate American influence in the drafting process. See Bush, supra note 18, at 519, 538. See also Cassese, supra note 15, at 353 ("This scheme [the IMT structure and rules] was first drawn up in 1944 by an American officer . . . refined by other staff, subsequently upheld by the US Secretary of War Henry L. Stimson and finally accepted by the other three Great Powers in London in 1945.").

66371 U.S. 471 (1963).

67372 U.S. 335 (1963).

68 It should be noted that at the time of Nuremberg, the United States Supreme Court had interpreted due process as ensuring counsel to all defendants in capital cases, which the Nuremberg cases also were. See Powell v. Alabama, 287 U.S. 45 (1932).

69373 U.S. 83 (1963).

70377 U.S. 201 (1964).

71384 U.S. 436 (1966).

72386 U.S. 18 (1967). 
rights may not be treated as harmless error); United States v. Wade ${ }^{73}$, Gilbert v. California $^{74}$, Stovall v. Denno ${ }^{75}$ (mandated procedures to minimize mistaken identification); Bruton v. United States ${ }^{76}$ (admission of non-testifying co-defendant's confession denies defendant his rights under the Confrontation Clause); Duncan v. Louisiana ${ }^{77}$ and Baldwin v. New York ${ }^{78}$ (jury trial required where possible penalty exceeds six months' imprisonment); and Terry v. Ohio ${ }^{79}$ (prerequisite to "stop-and-frisk" is reasonable and articulable suspicion of criminal activity).

Thus, when viewed in the proper chronological context, the predominantly American drafters of the Nuremberg Charter might be said to have "held themselves to so much a higher legal standard ... when federal courts at home took only infrequent steps to insure the fairness of state investigatory and trial practices ..." ${ }^{80}$ Exceeding the protections already contemplated explicitly in the text of its Charter, the IMT provided in practice for a presumption of innocence, ${ }^{81}$ a beyond-a-reasonable-doubt standard of proof $^{82}$ and a prohibition against trying mentally incompetent defendants. ${ }^{83}$ It also permitted defendants, upon motion, to examine documentary evidence in the hands of occupation authorities; "in effect given access to the prosecution's principal source of evidence." ${ }^{84}$ In fact, within the relative criminal procedure vacuum of 1945, Nuremberg's fledgling due process standards are considered by some to have adequately "paid respect to the rights of the accused." 85 Considering "the atrocities that had taken place and the suffering that was involved," these commentators conclude that the Nuremberg procedure was fundamentally "fair." 86 In fact, Professor Zappalà concludes: "It is very difficult to deny that under those circumstances it was difficult to conduct a

73388 U.S. 218 (1967).

74388 U.S. 263 (1967).

75388 U.S. 293 (1967).

76391 U.S. 123 (1968).

77391 U.S. 145 (1968).

78399 U.S. 66 (1970).

79392 U.S. 1 (1968).

${ }^{80}$ Bush, supra note 18 , at 537.

${ }^{81}$ See, e.g., the Schacht Decision, supra note 42, at 555; Bush, supra note 18, at 531-32. Likewise, Professor Zappalà observes that "although the Nuremberg and Tokyo Charters did not explicitly recognize the presumption of innocence, it may be argued that it was accepted de facto. Indeed, Robert Jackson, the US Prosecutor at the [IMT], conceded that 'we accept that [the defendants] must be given a presumption of innocence." Zappalà, supra note 3 , at 84.

${ }^{82}$ See, e.g., the Schacht Decision, supra note 42, at 555; Bush, supra note 18, at 531-32.

${ }^{83}$ Bush, supra note 18, at 532-33. Bush cites to the example of the notorious Nazi industrialist Gustav Krupp. On the eve of trial, Krupp was found to be mentally incompetent. Over the strenuous objections of the prosecution, Krupp's case was severed. Id.

${ }^{84}$ Bush, supra note 18 , at 528.

${ }^{85}$ See, e.g., Safferling, supra note 12, at 22. Bassiouni, supra note 6, at 407-08 ("The legal amalgamation, according to Justice Jackson, worked to the advantage of the defendants in that they could, for example, take the stand and testify under oath in their own defense or simply present an unsworn statement to the court at the end of a trial without submitting to cross-examination.").

${ }^{86}$ Id. See also Bush, supra note 18, at 528. Bush points as well to Nuremberg's acquittals, such as the not-guilty verdict of former German Finance Minister Hjalmar Schacht (see Schacht Decision, supra note 42 , at 555) as further proof of its inherent fairness. Bush, supra note 18, at 528. 
fairer trial." ${ }^{, 87}$ These observations seem to vindicate Chief Prosecutor Robert Jackson's oft-quoted opening that certainly paid obeisance to due process:

There is a dramatic disparity between the circumstances of the accusers and the accused that might discredit our work if we should falter in even minor matters, in being fair and temperate ... We must never forget that the record on which we judge these defendants is the record on which history will judge us tomorrow. To pass these defendants a poisoned chalice is to put it to our lips as well. We must summon such detachment and intellectual integrity to our task that this trial will commend itself to posterity as fulfilling humanity's aspirations to do justice. ${ }^{88}$

As demonstrated above, in Nuremberg's wake, and perhaps partly because of Nuremberg, an international due process revolution would soon take place. The achievements of that revolution would be reflected in the next phase of developing an international criminal procedure: the advent of the ad hoc tribunals for the former Yugoslavia and Rwanda.

B. The Ad Hoc Tribunals for the Former Yugoslavia and Rwanda

After the global conflagration that gave rise to Nuremberg, the Cold War had an extreme chilling effect on the growth of international criminal law. ${ }^{89}$ With the end of bipolar hostilities in the early 1990s, though, ethnic tensions, which had been quelled in certain parts of the world during the hegemonic post-War years, began bubbling to the surface. In the former Yugoslavia and in Rwanda they exploded into "ethnic cleansing" and genocide. ${ }^{90}$

In February 1993, pursuant to Chapter VII of the U.N. Charter, the Security Council declared that ethnic atrocities committed in the former Yugoslavia constituted "a threat to international peace," and that the establishment of an ad hoc international criminal tribunal would "contribute to the restoration of peace."91 As a result, the Security Council directed the Secretary-General to prepare a report setting out the necessary details for implementing its decision to create a tribunal. ${ }^{92}$ On May 8, 1993, the Secretary-General submitted the requested report to the Security Council with a proposed Statute for a tribunal. ${ }^{93}$ On May 25, 1993, the Security Council created the

${ }^{87}$ Zappalà, supra note 3, at 46 n. 49.

882 Trial Of The Major WAR CRIMINALs Before The INTERNATIONAL Military Tribunal 101 (1949). See also Christensen, supra note 13, at 394.

89 See Cassese, supra note 15 , at 334.

90 Id. at 335.

91 S.C. Res. 808, U.N. SCOR, 48th Sess., 317th mtg. at 1, U.N. Doc. S/RES/808 (1993).

92 Id.

93 See The Secretary-General, Report of the Secretary-General Pursuant to Paragraph 2 of Security Council Resolution 808 (1993) [hereinafter Report of the Secretary-General], U.N. Doc. S/2504 (1993), 
International Criminal Tribunal for the Former Yugoslavia ("ICTY") by adopting the proposed Statute. $^{94}$

Soon thereafter, the Security Council responded in a similar way to the 1994 genocide in Rwanda. Once again acting under its Chapter VII powers, it created the International Criminal Tribunal for Rwanda ("ICTR") by Resolution 955 of November 8, 1994. ${ }^{95}$ The ICTR is governed by its Statute, which is annexed to Security Council Resolution $955 .^{96}$

The ICTY adopted its Rules of Procedure and Evidence ("RPE") on February 11, 1994. The rules came into force on March 14, 1994. ${ }^{97}$ The ICTY acted pursuant to Article 15 of its Statute mandating it to adopt "rules of procedure and evidence for the conduct of the pre-trial phase of the proceedings, trials and appeals, the admission of evidence, the protection of victims and witnesses, and other appropriate matters." 98 Similarly, in accord with Article 14 of its Statute, the ICTR adopted its own RPE, which became effective on June 29, 1995 [hereinafter ICTR RPE]. ${ }^{99}$

In terms of human rights, the world in which these RPEs were formulated bore little resemblance to that of 1945, when a new international criminal procedure was cut out of whole cloth for Nuremberg. As one commentator has observed: "...fifty years have elapsed since the Nuremberg prosecutions began and human wisdom has become increasingly conscious of the prohibitions against violating fundamental human rights..." ${ }^{100}$ By the 1990 s, that knowledge had inspired the globe to embrace a plethora of human rights instruments in addition to the ones already discussed above, including, inter alia: the Geneva Conventions, ${ }^{101}$ the Genocide Convention, ${ }^{102}$ the Convention Against

reprinted in 32 I.L.M. 1163. The annex to this Report contains the Statute of the tribunal. Id., Annex at 36, U.N. Doc. S/25704 (1993), 32 I.L.M. 1192.

94 Statute of the International Tribunal for the Prosecution of Persons Responsible for Serious Violations of International Humanitarian Law Committed in the Territory of the Former Yugoslavia since 1991, S.C. Res. 827, U.N. SCOR, 48th Sess., 3217 mtg. at 1, U.N. Doc. S/RES/827 (1993), reprinted in 32 I.L.M. 1203, 1204 [hereinafter ICTY Statute].

95 S.C. Res. 955, U.N. SCOR, 49th Sess., 3453d mtg. at 1, U.N. Doc. S/RES/955 (1994).

96 Statute of the International Criminal Tribunal for the Prosecution of Persons Responsible for Genocide and Other Serious Violations of Humanitarian Law Committed in the Territory of Rwanda and Rwandan Citizens Responsible for Genocide and Other Such Violations Committed in the Territory of Neighboring States, Between 1 January 1994 and 31 December 1994, S.C. Res. 955, U.N. SCOR, 49th Sess., Annex, 3453d mtg., U.N. Doc. S/RES/955 (1994) [hereinafter ICTR Statute].

${ }^{97}$ ICTY Rules of Procedure and Evidence, U.N. Doc. IT/32 (1994) [herinafter ICTY RPE].

98 Report of the Secretary-General, supra note 84.

99 The ICTR Rules of Procedure and Evidence [hereinafter ICTR RPE] "do not carry a UN document number." Mark A. Drumbl \& Kenneth S. Gallant, Appeals in the Ad Hoc International Criminal Tribunals: Structure, Procedure, and Recent Cases, 3 J. APP. PRAC. \& ProCESS 589, 609 n.100 (2001).

${ }^{100}$ Father Robert Araujo, Sovereignty, Human Rights and Self-Determination: The Meaning of International Law, 24 FORDHAM INT'L L. J. 1477, 1489 (2001).

101 Four Geneva Conventions for the Protection of Victims of Armed Conflict, 6 U.S.T. 3114, 3217, 3316, 3516, 75 U.N.T.S. 31, 85, 135, 287, entered into force Oct. 21, 1950.

102 Convention on the Prevention and Punishment of the Crime of Genocide, 78 U.N.T.S. 277, entered into force Jan. 12, 1951. 
Torture, ${ }^{103}$ the Convention on Elimination of Racial Discrimination, ${ }^{104}$ the Convention on the Rights of the Child, ${ }^{105}$ the Convention on the Elimination of All Forms of Discrimination Against Women, ${ }^{106}$ and the International Covenant on Economic, Social and Cultural Rights. ${ }^{107}$

These treaties, and the strengthening of human rights they embodied, presaged an expansion of due process guarantees for defendants at the two ad hoc Tribunals. As one commentator has noted:

One of the most fundamental principles of human rights, as stated above, 'is the protection of individual liberty, especially from the undue exercise of state power.' This principle is also applicable at the international level and the concern for personal liberty is reflected in the Statutes of the ICTY and ICTR and their Rules of Procedure and Evidence. These instruments limit the extent to which persons may be deprived of their liberty before they are brought to trial and set out rules aimed at preventing the innocent from being convicted and imprisoned by protecting the integrity of the trial itself. ${ }^{108}$

Accordingly, the due process advances of the two ad hoc Tribunals may be gleaned from a distillation of their structures and rules. Since the ICTR "adopted most rules of [the] ICTY without major amendment," ${ }^{109}$ this section of the Article will focus on the ICTY's structure and rules. ${ }^{110}$

103 Convention Against Torture and Other Cruel, Inhuman, or Degrading Treatment or Punishment, 1465 U.N.T.S. 113, entered into force June 26, 1987.

104 Convention on the Elimination of Racial Discrimination, 660 U.N.T.S. 195, entered into force Jan. 4, 1969.

105 Convention on the Rights of the Child, 1577 U.N.T.S. 3, entered into force Sept. 2, 1990.

106 Convention on the Elimination of All Forms of Discrimination Against Women, 1249 U.N.T.S. 13, entered into force Sept. 3, 1981.

107 International Covenant on Economic, Social and Cultural Rights, 993 U.N.T.S. 3, entered into force Jan. 3, 1976.

108 Stuart Beresford, Redressing the Wrongs of the International Justice System: Compensation for Persons Erroneously Detained, Prosecuted, or Convicted by the Ad Hoc Tribunals, 96 AM. J. INT'L. L. 628, 631 (2002).

109 Catherine Cissé, The International Tribunals for the Former Yugoslavia and Rwanda: Some Elements of Comparison, 7 TRANSNAT'L L. \& CONTEMP. PROBS. 103, 116 (1997).

110 At the time the ICTR RPE was adopted, the only noteworthy difference between it and the ICTY RPE related to the rule on provisional measures during investigations. ICTR RPE Rule 40 permitted the Prosecutor "upon showing that a major impediment does not allow the State to keep the Suspect under provisional detention ... apply to a Judge ... for an order to transfer the suspect to the seat of the Tribunal ... and to detain him there provisionally. [Thereafter the] suspect shall be released if: i) the Chamber so rules, or ii) the Prosecutor fails to issue an indictment within twenty days of the transfer." ICTR RPE, supra note 99, R. 40 (1995). See Cissé, supra note 109, at 116-17. This exception to the rule of nondetention was not subsequently expanded in Rule 40 of the ICTY. Id. 


\section{Structure}

The organizational chart of the ICTY can be divided into three principal functions: adjudicative, prosecutorial and administrative. ${ }^{111}$ These respective functions are assigned to three principal and separate organs: (1) the Chambers (including three Trial Chambers and one Appeals Chamber), (2) the Prosecutor and (3) the Registry. ${ }^{112}$

The Registry, which is responsible for all administrative matters relating to the ICTY, serves both the Prosecutor and the Chambers. ${ }^{113}$ Unlike the Nuremberg Tribunal, the ICTY (and ICTR, for that matter) is truly international -- prosecutors, judges and members of the registry come from countries around the world. ${ }^{114}$

Of these three ICTY organs, the Office of the Prosecutor plays perhaps the most significant role in determining the Tribunal's agenda. It is tasked with investigating, preparing indictments, and trying alleged criminals. ${ }^{115}$ The Prosecutor initiates investigations ex officio -- in other words, without the review or authorization of any other Tribunal organ. ${ }^{116}$

\section{Procedure}

In general, there are six procedural steps in the ICTY's pre-trial stage. ${ }^{117}$ First, as just described, the Prosecutor initiates the investigation. During the investigation phase, the Prosecutor has the power to question suspects, victims, and witnesses, to collect evidence, and to conduct on-site investigations. ${ }^{118}$ In carrying out these tasks, the Prosecutor may, as appropriate, seek the assistance of the State authorities concerned. ${ }^{119}$ ICTY RPE Rule 40 authorizes the Prosecutor to request any State concerned, as a matter of urgency: (i) to arrest a suspect provisionally; (ii) to seize physical evidence; and (iii) to take all necessary measures to prevent the escape of a suspect or an accused, injury to or intimidation of a victim or witness, or the destruction of evidence.

Second, if the Prosecutor determines that a prima facie case exists, she prepares an indictment containing a concise statement of facts and crimes with which the accused

111 ICTY Statute, supra note 94, art. 11. See also Scott T. Johnson, On the Road to Disaster: The Rights of the Accused and the International Criminal Tribunal for the Former Yugoslavia, 10 INT'L LEGAL PERSP. 111, 142 (1998).

112 ICTY Statute, supra note 94, arts. $12-17$.

113 Id. art. 17.

114 See, e.g., id., art. 12 ("The Chambers shall be composed of sixteen permanent independent judges, no two of whom may be nationals of the same State ...").

115 Id. art. 16.

116 Id. art. 18.

117 Joseph L. Falvey, Jr., United Nations Justice or Military Justice: Which Is the Oxymoron? An Analysis of the Rules of Procedure and Evidence of the International Tribunal for the Former Yugoslavia, 19 FORDHAM INT'L L.J. 475, 488 (1995).

118 Id.

119 Id. 
is charged. ${ }^{120}$ Third, the Prosecutor transmits the indictment to a designated trial chamber judge. ${ }^{121}$ Fourth, the designated trial chamber judge confirms the indictment if she agrees that it presents a prima facie case. ${ }^{122}$ Otherwise, the judge dismisses the indictment. ${ }^{123}$ Fifth, if the indictment is confirmed, at the request of the Prosecutor or sua sponte, the judge may issue an arrest warrant for the accused if the accused is not already in the ICTY's custody. ${ }^{124}$ Finally, after the arrest and transfer of the accused to the control of the ICTY, he is brought before a trial chamber judge, "without delay," for an arraignment proceeding, during which a date for trial is scheduled. ${ }^{125}$

If the accused pleads guilty, and the Trial Chamber is satisfied that the guilty plea was informed, made voluntarily, not equivocal, and supported by a sufficient factual basis, then the Registrar will set a date for the sentencing hearing. ${ }^{126}$

Assuming the accused pleads not guilty, Article 21 of the ICTY Statute provides for a "fair" trial and enumerates various requirements to guarantee fairness. Those

${ }^{120}$ ICTY Statute, supra note 94, art. 18. See also ICTY RPE, supra note 97, R. 47(b). The ICTY RPE replaces the phrase "prima facie case" with the phrase "sufficient evidence to provide reasonable grounds for believing that a suspect has committed a crime." ICTY RPE, id. R. 47(A).

121 ICTY Statute, supra note 94, art. 18. An indictment may join two or more persons charged with the same crime or with different crimes committed in the course of the same transaction. ICTY RPE, supra note 97, R. 48. It may likewise charge an accused person (or persons) with two or more crimes, if those crimes form part of a series of crimes that constitute one transaction and were committed by the same accused person (or persons). Id. R. 49.

122 ICTY Statute, supra note 94, art. 19(1). An indictment may be amended without leave at any time before its confirmation. Thereafter, amendment must be by leave of the trial chamber. ICTY RPE, supra note 97, R. 50. Similarly, an indictment may be withdrawn without leave at any time before its confirmation. After that, it can be withdrawn only with the leave of the judge who confirmed it or, if at trial, with leave of the trial chamber. Id. R. 51. At the time of confirmation, the confirming judge may, in consultation with the prosecutor, order that there be no disclosure of the indictment until it has been served on the accused. Id. R. 53. Nondisclosure at this stage is intended to ensure that the accused does not, on hearing of the indictment, disappear so as to avoid arrest and trial. Id. R. 53(B). See also Daniel D. Ntanda Nsereko, A Critical Study of the International Tribunal for the Former Yugoslavia: Substantive and Procedural Issues, 5 CRIM. L. F. 507, 529 (1994).

123 ICTY Statute, supra note 94, art. 19 (1). The dismissal of an indictment or a count does not preclude the prosecutor from subsequently bringing a new indictment or count based on the acts underlying that indictment or count providing that there is additional evidence to support it. ICTY RPE, supra note 97, R. 47(E).

${ }^{124}$ ICTY Statute, supra note 94, art. 19 (2). See also ICTY RPE, supra note 97, R.R. 54-61. The warrant must be accompanied by a copy of the indictment and a statement of the accused's rights. Id., R. 55(C). The rights of the accused will be discussed infra. The state authorities to which the warrant is transmitted must execute it promptly and diligently. Id., R. 56. The local authorities cannot set up their national laws or existing treaty obligations as an excuse for not surrendering the accused, since the obligations they assume under Article 29 of the Statute [Co-operation and Judicial Assistance] override such laws or treaty obligations. Where the national authorities are unable to execute an arrest warrant, they must so report to the Registrar, giving the reasons for their inability. ICTY RPE, supra note 97, R. 59(A). If, after the lapse of a reasonable time, no report is made, "this shall be deemed a failure to execute the warrant of arrest" and the Tribunal, through the President, "may notify the Security Council accordingly." Id., R. 59(B).

${ }_{125}$ ICTY Statute, supra note 94, art. 20; ICTY RPE, supra note 97, art. 62.

126 ICTY RPE, supra note 97, art. 62 bis. 
requirements will be discussed infra. The rules provide for preliminary motions, ${ }^{127}$ a pretrial conference, ${ }^{128}$ and a "pre-defense" conference. ${ }^{129}$ The trial itself takes place before the trial chamber to which the matter has been assigned (i.e., the case is tried to three judges). ${ }^{130}$ The judgment must be rendered by a majority of the judges of the trial chamber (i.e., at least two of three) and must be delivered by the trial chamber in public. ${ }^{131}$ It must be accompanied by "a reasonable opinion in writing, to which separate or dissenting opinions may be appended." "132 Both the convicted defendant and the Prosecutor have the right to appeal the trial chamber's decisions (based on both errors of fact and law). ${ }^{133}$ The appeals chamber may affirm, reverse, or revise the decisions of the trial chamber. ${ }^{134}$

\section{Rights of the Accused}

The post-World War II advances in the due process rights of criminal defendants "are an explicit component of the [ICTY]'s legal framework."135 In his commentary regarding procedural issues and the rights of the accused at the time of the Tribunal's creation, the U.N. Secretary-General stated that it "is axiomatic that the International Tribunal must fully respect internationally recognized standards regarding the rights of the accused at all stages of its proceedings." 136 In fact, the due process guarantees incorporated into the ICTY Statute roughly reflect those found in Article 14 of the ICCPR, ${ }^{137}$ an instrument cited by the Secretary-General as reflective of the internationally recognized standards of the rights of criminal defendants. ${ }^{138}$ These rights of the accused, which are "subject" to the provisions of Article 22 (dealing with victimwitness protection), ${ }^{139}$ include:

127 ICTY RPE, id. R.R. 72, 73. These motions are brought before a specially designated "Pre-Trial Judge" who handles pre-trial issues between the parties, establishes a pre-trial litigation schedule, and enforces it. See id., R. 65 ter.

128 Id. R. 73 bis. This rule requires a conference before a specially designated "Pre-Trial Judge." See id., R. 65 ter. At the conference, the parties are supposed to discuss the number of witnesses the Prosecutor may call, the time available for the Prosecutor to present evidence, and the "number of crime sites or incidents in respect of which evidence may be presented ..." Id. R. 73 bis.

${ }^{129}$ Id. R. 73 ter. Pursuant to this rule, prior to the commencement by the defense of its case, the Trial Chamber may hold a conference to discuss various matters, including the number of witnesses the defense may call and the time granted to the defense to put on its case.

130 ICTY Statute, supra note 94, arts. $12 \& 23$.

131 Id. art. 23.

132 Id.

133 Id. art. 25.

134 Id.

135 Defrancia, supra note 4, at 1393 (2001).

136 Secretary-General's Report on Aspects of Establishing an International Tribunal for the Prosecution of Persons Responsible for Serious Violations of International Humanitarian Law Committed in the Territory of the former Yugoslavia, 1 106, U.N. SCOR, $48^{\text {th }}$ Sess., Annex, U.N. Doc. s/25704 (1993), reprinted in 32 I.L.M. 1159 (1993) [hereafter Secretary-General's Report].

137 ICCPR, supra note 57, art. 21.

138 Secretary-General's Report, supra note 136, ๆ 106.

139 ICTY Statute, supra note 94, art. 22, [Protection of victims and witnesses] which declares: "The International Tribunal shall provide in its rules of procedure and evidence for the protection of victims and witnesses. Such protection measures shall include, but shall not be limited to, the conduct of in camera proceedings and the protection of the victim's identity." 
(a) To be informed promptly and in detail in a language which he understands of the nature and cause of the charge against him;

(b) To have adequate time and facilities for the preparation of his defense and to communicate with counsel of his own choosing;

(c) To be tried without undue delay;

(d) To be tried in his presence, and to defend himself in person or through legal assistance of his own choosing; to be informed, if he does not have legal assistance, of this right; and to have legal assistance assigned to him, in any case where the interests of justice so require, and without payment by him in any such case if he does not have sufficient means to pay for it;

(e) To examine, or to have examined, the witnesses against him and to obtain the attendance and examination of witnesses on his behalf under the same conditions as witnesses against him;

(f) To have the free assistance of an interpreter if he cannot understand or speak the language used in the International Tribunal; and

(g) Not to be compelled to testify against himself or to confess guilt. $^{140}$

The above-enumerated ICCPR Article 14 rights, only referring to "hearings before a tribunal," 141 do not paint the entire due process picture at the ICTY because "the commencement of investigations can hardly be understood as a hearing before a tribunal."142 Indeed, both the ICTY Statute and RPE contain additional investigativephase protections. Article 18(3) of the Statute provides: "If questioned, the suspect shall be entitled to be assisted by counsel of his own choice, including the right to have legal assistance assigned to him without payment by him in any such case if he does not have

\footnotetext{
140 Id. art. 21(4). Pursuant to Rule 82 of the ICTY RPE [Joint and Separate Trials], in joint trials, each accused shall have the same rights as if such accused were being tried separately. Moreover, the Trial Chamber may order that persons accused jointly under Rule 48 be tried separately if it considers it necessary "in order to avoid a conflict of interest that might cause serious prejudice to an accused or to protect the interests of justice." ICTY RPE, supra, note 94, R. 82.

141 Safferling, supra note 12 , at 56.

142 Id.
} 
sufficient means to pay for it, as well as to necessary translation into and from a language he speaks and understands." 143

The RPE goes further. Pursuant to Rule 42, a suspect who is to be questioned by the Prosecutor is accorded the following rights, of which the Prosecutor must inform the suspect prior to questioning, in a language the suspect understands:

(a) The right to be assisted by counsel of the suspect's choice or to be assigned legal assistance without payment if the suspect does not have sufficient means to pay for it;

(b) The right to have the free assistance of an interpreter if the suspect cannot understand or speak the language to be used for questioning; and

(c) The right to remain silent, and to be cautioned that any statement the suspect makes shall be recorded and may be used in evidence. ${ }^{144}$

Moreover, questioning of the suspect may not take place without the presence of counsel unless the suspect has waived the right to counsel. ${ }^{145}$ Nevertheless, even in the case of waiver, if the suspect subsequently expresses a desire to have counsel, the Prosecutor must stop the questioning and may resume only when the suspect has obtained counsel. ${ }^{146}$ Finally, whenever a prosecutor questions a suspect, Rule 43 of the RPE requires that the session be audio or video-recorded. ${ }^{147}$ According to Professor Christopher Safferling this "is the most effective safeguard against undue pressure from the interrogator" and it "enhances the ICTY's ability to determine whether a statement was made voluntarily." 148

As a means of enforcing these safeguards, RPE Rule 95 bars admission of any evidence "obtained by methods which cast substantial doubt on its reliability" or whose admission would be "antithetical to, and would seriously damage, the integrity of the proceedings." 149

143 ICTY Statute, supra note 94, art. 18(3).

144 ICTY RPE, supra note 94, R. 42(A).

145 Id., R. 42(B).

146 Id. These custodial interrogation protections are comparable to those afforded defendants in the United States Supreme Court decision of Miranda v. Arizona, supra note 71, and its progeny. See Safferling, supra note 12, at 123 n.369 (disagreeing with the notion that the "law at the ICTY deviates from the Miranda jurisprudence. .."). If anything, the ICTY, as befits an international tribunal, goes above and beyond the Miranda protections by providing for the free assistance of an interpreter and the requirement that the questioning be recorded (as explained infra).

147 ICTY RPE, supra note 97, R. 43.

148 Safferling, supra note 12, at 130.

149 ICTY RPE, supra note 97. R. 94. 
Other rights are embedded in various articles of the Statute. For example, pursuant to Article 13, the accused has the right to be tried by judges of high moral character, impartiality and integrity who possess experience in criminal and international law and qualifications required in their respective countries for appointment to the highest judicial offices. ${ }^{150}$ Article 10 incorporates the principle of "ne bis in idem," an equivalent to the American double jeopardy protection that essentially prevents a person from being tried twice for the same crime. ${ }^{151}$ As for sentencing, in contrast to Nuremberg, the ICTY does not permit punishment by death. ${ }^{152}$ Similarly, also different from Nuremberg, it allows defendants to appeal their convictions. ${ }^{153}$

\section{The International Criminal Court}

In a decade whose opening ended the Cold War and ushered in mass internecine violence in Europe and Africa and whose middle resuscitated the dormant dreams of Nuremberg, it was perhaps fitting that the 1990s should close with the creation of a permanent global criminal tribunal. The Rome Statute of the International Criminal Court ("Rome Statute") was signed on July 17, 1998 at the United Nations Diplomatic Conference of Plenipotentiaries on the Establishment of an International Criminal Court ("ICC"). ${ }^{154}$ Two years later, the ICC adopted its Rules of Procedure and Evidence. ${ }^{155}$

The ICC has been described as "the culmination of five decades of progress toward the realization of protection for human rights throughout the world." 156 As a result, the ICC represents the most advanced level of protection to date of the rights of defendants in international criminal proceedings. ${ }^{157}$ This growth in due process

150 ICTY Statute, supra note 94, art. 13.

151 Id. art. 10. See Johan van der Vyver, Prosecution and Punishment of the Crime of Genocide, 23 FORDHAM INT'L L. J. 286, 342 (1999) (equating ne bis in idem with the double jeopardy protection). Nevertheless, a person who has been tried by a national court for acts constituting violations of international humanitarian law may be subsequently tried by the ICTY only if: (a) the act for which he was tried was characterized as an ordinary crime; and (b) the national court proceedings were not impartial or independent, were designed to shield the accused from international criminal responsibility, or the case was not diligently prosecuted. ICTY Statute, supra note 94, art. 10.

152 See ICTY Statute, supra note 94, art. 24 (providing that any penalty to be imposed by the ICTY shall be limited to imprisonment).

${ }^{153} I d$. art. 25 (providing for appellate proceedings).

154 Rome Statute of the International Criminal Court, July 17, 1998, 2187 U.N.T.S. 3, reprinted in 1 United Nations Diplomatic Conference of Plenipotentiaries on the Establishment of an International Criminal Court, Official Records (1998) [hereinafter Rome Statute].

155 Finalized Draft Text of the Rules of Procedure and Evidence, Preparatory Commission for the International Criminal Court, U.N. Doc. PCNICC/2000/1/Add.1 (July 2000) [hereinafter ICC RPE]. The Rome Statute entered into force on July 1, 2002 and the ICC began operating in March 2003. See Dawn Yamane Hewitt, Sudan's Courts and Complementarity in the Face of Darfur, 31 YALE J. INT'L L. 276, 277 (2006). To date, the ICC has pending investigations in Uganda, the Democratic Republic of the Congo (DRC), and Darfur. Uganda and the DRC are State Parties to the Rome Statute and conferred jurisdiction upon the ICC through self-referral. Id. In contrast, the ICC obtained jurisdiction over the Darfur case through the U.N. Security Council referral. Id.

${ }^{156}$ Jeremy Rabkin, The Politics of the Geneva Conventions: Disturbing Background to the ICC Debate, 44 VA. J. INT'L L. 169, 171 (2003).

157 Zappalà, supra note 3, at 25 \& 48 ("It is indisputable that, in the ICC Statute, there has been a clear attempt to improve the protection of rights relating to the administration of criminal justice.”). 
safeguards, however, is not merely an incidental byproduct of a cresting human rights trend. Instead, "for the first time in history, these [ICC criminal procedure] rules were adopted by States clearly having in mind that one day these rights might be applicable to proceedings instituted against their own citizens." $" 158$

Nevertheless, rather than re-invent the proverbial wheel, the ICC's criminal procedure takes the ad hoc Tribunals for the former Yugoslavia and Rwanda as its starting point. As a result, the ICC incorporates much of the structural and due process elements of the ad hoc tribunals. ${ }^{159}$ Still, to analyze the ICC's due process expansion vis $\grave{a}$ vis the ad hoc tribunals, its structure, rules and rights should be examined independently.

\section{Structure}

With some slight modifications, the basic organic structure of the ICC largely resembles those of the ad hoc Tribunals. ${ }^{160}$ Article 34 of the Rome Statute states that the ICC shall be composed of the following organs: the Presidency, in other words, the President and the First and Second Vice-Presidents under Article 38 (comprising the main steering committee of the Court); an Appeals Division, a Trial Division, and a PreTrial Division (those four "organs" composing the Court proper); the Office of the Prosecutor; and the Registry. ${ }^{161}$ The Presidency and the various judicial chambers are responsible for the Court's judicial function. The Office of the Prosecutor carries out the ICC's investigative and prosecutorial functions. And the Registry is the principal administrative organ of the Court. ${ }^{162}$

The Statute allows for eighteen full-time judges (including members of the Presidency). ${ }^{163}$ The Appellate Division is composed of the President and four other judges, while the Trial and Pre-Trial Divisions each require not less than six judgeships. ${ }^{164}$ Each Trial Chamber consists of three judges while each Pre-Trial Chamber may consist of three judges or a single judge "in accordance with [the] Statute and the Rules of Procedure and Evidence." 165

158 Id.

159 See Theodor Meron, War Crimes Law Comes of Age, 92 AM. J. InT’L L. 462, 463 (1998) (“. . . the rules of procedure and evidence each Tribunal has adopted now form the vital core of an international code of criminal procedure and evidence that will doubtless have an important impact on the rules of the future international criminal court."); Scott Luftglass, Crossroads in Cambodia: The United Nations' Responsibility to Withdraw from the Establishment of a Cambodian Tribunal to Prosecute the Khmer Rouge, 90 VA. L. REV. 893, 953 (2004) ("The ICC will have jurisdiction over genocide, crimes against humanity and serious war crimes, meaning that it will rely on the procedures, holdings, and lessons of the ICTY [and] the ICTR ...”).

160 See Caianiello \& Illuminati, supra note 5, at 433 ("The structure of the ICC is similar to that of the International Tribunals.").

161 Rome Statute, supra note 154 , arts. $34 \& 38$.

162 See Gregory P. Noone \& Douglas William Moore, An Introduction to the International Criminal Court, 46 NAVAL L. REV. 112, 124 (1999).

${ }^{163}$ Rome Statute, supra note 154 , arts. $35 \& 36$.

164 Id. art. 39.

165 Id. 
The Office of the Prosecutor is primarily responsible for "receiving referrals and any substantiated information on crimes" within the ICC's jurisdiction and "conducting investigations and prosecutions before the Court."166 The Registry, acting under the authority of the Presidency, deals with the "non-judicial aspects of the administration and servicing of the Court, without prejudice to the functions and powers of the Prosecutor.",167

\section{Procedure}

Proceedings at the ICC may be initiated in one of three ways. The first two ways consist of (1) the Security Council (acting under Chapter VII of the United Nations Charter) or (2) a State Party referring a crime or crimes to the Prosecutor for investigation. ${ }^{168}$ The third way entails the Prosecutor's initiating a proceeding "proprio motu (i.e., on the Prosecutor's own motion) on the basis of information on crimes within the jurisdiction of the Court." 169

In the case of investigations initiated by State Parties or proprio motu, as a threshold matter, the Prosecutor must first determine whether "there would be a reasonable basis to commence an investigation."170 If the Prosecutor is satisfied that there is such a basis, he must notify "all States Parties and those States, which, taking into account the information available, would normally exercise jurisdiction over the crimes concerned." $" 171$ Only if there is no relevant State criminal investigation/prosecution taking place, or if one taking place is clearly "unwilling or unable" to do justice, may the Prosecutor initiate investigations proper. ${ }^{172}$

In the case of proprio motu initiation, Article 15 requires that a preliminary investigation or "inquiry," ${ }^{173}$ precede an investigation proper. The "inquiry" consists of a search for information or the gathering of evidence about an alleged crime, for the

166 Id. art. 42.

167 Id. art. 43.

168 Id. arts. 13 [Security Council and State Party referral] \& 14 [State Party referral].

169 Id. art. 15. This means the Prosecutor is acting without the referral or authorization of the Security Council or State Parties. See also id. art. 53 ("Initiation of an Investigation").

170 Id. arts. $18(1) \& 53(1)$.

171 Id. art. 18(1). In case of referral by the Security Council, the Prosecutor may find other means of enabling States to become cognizant of the referral and of the possible initiation of court investigations. See Cassese, supra note 15 , at 408.

172 Rome Statute, supra note 154, arts. 17 \& 18. See also Cassese, supra note 15, at 409. This comports with the principle of "complementarity." See Safferling, supra note 12, 177. "Complementarity" is defined as "deferral by the ICC to the courts of national jurisdiction of the accused." Gerard E. O'Connor, The Pursuit of Justice and Accountability: Why the United States Should Support the Establishment of an International Criminal Court, 27 HOFSTRA L. REV. 927, 948 (1999). "At the core of determining who will have jurisdiction in a particular case, complementarity recognizes that the ICC will not supersede or replace national courts, but will rather seek to complement them. There will be a presumption that the Prosecutor will be precluded from taking any action when a state has a functioning judicial system." Noone \& Moore, supra note 162, at 140-41.

173 This is the term used by Professor Cassese for purposes of conceptual and procedural clarity. See Cassese, supra note 15 , at 407. 
purpose of establishing if there is "a reasonable basis to proceed with the investigation." 174 The Prosecutor bases the initiation of this proprio motu inquiry on any relevant information he may have received from any reliable source, as well as "written or oral testimony at the seat of the Court." ${ }^{, 175}$ If the Prosecutor establishes that such a "reasonable basis" exists, he must submit to the Pre-Trial Chamber a "request for authorization of an investigation." 176 If the Pre-Trial Chamber grants the request, the Prosecutor may commence the investigation. ${ }^{177}$

Notwithstanding this authorization, the Security Council, by mere request to the Court through a resolution adopted under Chapter VII of the U.N. Charter, will obtain a twelve-month suspension of any investigation or prosecution, either before its commencement or while it is under way. ${ }_{178}$ Moreover, the Security Council may renew such a request under the same conditions. ${ }^{179}$

Assuming the investigation goes forward, however, the Prosecutor is not merely an adversarial party to the proceedings. As set forth in Article 54 of the Rome Statute, she is bound to search for, gather, and pass on to the defense both incriminating and exonerating evidence equally. ${ }^{180}$ In this sense, the Prosecutor acts as an "organ of justice" rather than just an opposing party in a contest. ${ }^{181}$

During the investigation, the Prosecutor has no power to take forcible measures on the territory of a State. ${ }^{182}$ This is owing to Article 99 of the Rome Statute, which affords the Prosecutor rather limited powers to conduct on-site investigations. ${ }^{183}$ This entails that "intrusive measures, such as searches and seizures will have to be executed by the State Party upon request by the ICC."

Once the investigation is initiated, the Prosecutor must apply to the Pre-Trial Chamber for the issuance of an arrest warrant or a summons to appear before the Court. ${ }^{185}$ A State must promptly surrender the designated person to the Court after the State's judiciary determines that the person's identity matches that of the warrant and all

\footnotetext{
174 Rome Statute, supra note 154, art. 15; Cassese, supra note 15, at 407.

175 Rome Statute, supra note 154, art. 15(1).

176 Id. art. 15(3).

177 Id. art. 15(4).

178 Id. art. 16.

179 Id.

180 Id. art. 54.

181 See Cassese, supra note 15, at 439.

182 See Claus Kress, The Procedural Law of the International Criminal Court in Outline: Anatomy of a Unique Compromise, 1 J. INT'L CRIM. JUST. 603, 615 (2003). This is with the "arguable exception of the 'failed state scenario' under Article 57(3)(d) of the Rome Statute." Id. Article 57(3) empowers the PreTrial Chamber to authorize the Prosecutor to take specific investigative steps within the territory of a State Party without having secured the cooperation of that State, when the State is clearly unable to execute a request for cooperation. Rome Statute, supra note 154, art. 57(3).

183 Rome Statute, supra note 154, art. 99(4).

184 Kress, supra note 182, at 615.

185 Id. art. 58.
} 
corresponding rights have been respected. ${ }^{186}$ Once the suspect is placed in the Pre-Trial Chamber's custody, a hearing, in the presence of the suspect and his counsel, is conducted to confirm the charges on which the Prosecutor intends to try the case. ${ }^{187}$ Before the Chamber rules on the sufficiency of evidence to bind the suspect over for trial, the suspect is permitted at the hearing to object to the charges, challenge the Prosecutor's evidence, and present his own evidence. ${ }^{188}$

During the pre-trial phase, the suspect may apply to the Pre-Trial Chamber for "interim release" pending trial. ${ }^{189}$ Also during this phase, the Prosecutor may amend the charges after giving notice to the accused and provided that the Pre-Trial Chamber permits the amendment. ${ }^{190}$ It is also during this phase that the Prosecutor must proceed to the disclosure of collected "evidentiary" materials and the defense must disclose certain matters to the Prosecution, including the assertion and substance of any alibi defense. ${ }^{191}$ Relying on the trial procedures established by the ad hoc Tribunals, "a similar system is envisaged for the ICC." 192

\section{Rights of the Suspect and the Accused}

The ICC has been described as "explicitly bound by respect for human rights."193 Indeed, pursuant to Article 54 of the Rome Statute, the Prosecutor must "fully respect the

186 Id. art. 59.

187 Id. art. 61. The hearing can be held in the absence of the person charged only if he has waived the right to be present, or if he has fled or cannot be found, meaning a warrant or a summons was issued having no effect. Id., art 61(2). If the suspect has fled or cannot be found, all reasonable steps must have been taken to secure his appearance and to inform him of the hearing and the charges. Id. In such cases, the absent person may be represented by counsel, but this right is subject to discretionary review by the PreTrial Chamber to determine whether it is in the interest of justice. Id.

${ }^{188}$ Id. If the Chamber declines the charge, the Prosecutor may subsequently request confirmation upon the presentation of additional evidence. $I d$.

189 Id. art. 60. The ICC will not grant interim release if it is satisfied that the conditions set forth in art. 58, paragraph 1 are met. Under these, detention must be ordered if necessary: (1) to ensure the person's appearance at trial; (2) to ensure that the person does not obstruct or endanger the investigation or the court proceedings; or (3) where applicable, to prevent the person from continuing with the commission of that crime, or a related crime which is within the jurisdiction of the Court and which arises out of the same circumstances. "It comes as no surprise that strict conditions govern the interim release applications, because they were driven by the fear that detention might too easily be suspended." Göran Sluiter, The Surrender of War Criminals to the International Criminal Court, 25 LOY. L.A. INT'L. \& COMP. L. REV. 605,623 (2003). The suspect may similarly apply for interim release, if he can show the absence of the same conditions, when in the custody of the State that arrested him (i.e., pre-surrender to the ICC). See Rome Statute, supra note 154, art. 59.

190 Rome Statute, supra note 154, art. 61(9).

191 ICC RPE Rules 76-84 govern these matters. ICC RPE, supra, note 155, R.R. 76-84.

192 Cassese, supra note 15, at 421. Under ICC RPE Rule 141(2), "the defense shall always have the opportunity to speak last." ICC RPE, supra note 155, R. 141(2). Additionally, matters related to sentencing must be separately addressed by the parties, before the end of trial, in "additional hearings." See Rome Statute, supra note 154, art. 76; ICC RPE, supra note 155, R. 143. The ad hoc Tribunals originally had a separate post-trial sentencing phase but this feature was eliminated in July 1998 in the interests of streamlining the proceedings. See Andrew N. Keller, Punishment for Violations of International Criminal Law: An Analysis of Sentencing at the ICTY and ICTR, 12 IND. INT'L \& COMP. L. REV. 53, 67 (2001).

193 Zappalà, supra note 3 , at 43 . 
rights of persons arising under this Statute." ${ }^{\prime 194}$ Further, Article 21 makes clear that the ICC is bound by "principles and rules of international law" and that its interpretation of law must be "consistent with internationally recognized human rights." 195

\section{a. Pre-Trial Rights}

During the pre-trial phase, the nomenclature for persons under investigation is bifurcated into (1) persons in respect of an investigation; and (2) persons for whom there are grounds to believe they committed a crime within the jurisdiction of the Court. ${ }^{196}$ For the former, Paragraph 1 of Article 55 explicitly guarantees the following due process protections:

(a) The right not to incriminate oneself or confess guilt;

(b) The right not to be subjected to any form of coercion, duress or threat, to torture or to any other form of cruel, inhuman, or degrading treatment or punishment;

(c) The right to an interpreter and to such translations as are necessary to meet the requirements of fairness; and

(d) The right not to be subjected to arbitrary arrest or detention and not to be deprived of liberty except on such grounds and in accordance with such procedures as are established in the Statute. ${ }^{197}$

Sub-section (d) above does not specify which "procedures" established in the Statute would apply. However, the grounds for arrest and certain guarantees for persons arrested are laid out elsewhere in the Statute. Article 58, for example, specifies that the arrest warrant must contain concise information for the arrested person concerning the reasons for the arrest and the crimes allegedly committed. ${ }^{198}$ Article 58 also specifies the grounds on which the Pre-Trial Chamber may issue a warrant of arrest. In the first place, there must be reasonable grounds for believing the person has committed a crime within the jurisdiction of the Court. ${ }^{199}$ Moreover, the arrest must be necessary to ensure the attendance of that person at trial, to prevent obstruction of investigations, and, where applicable, to prevent the commission of other related crimes. ${ }^{200}$

\footnotetext{
194 Rome Statute, supra note 154, art. 54.

195 Id. art. 21.

196 Id. art. 55.

197 Id.

198 Id. art. 58.

199 Id.

200 Id.
} 
One other important arrest-related right must be mentioned. ${ }^{201}$ Article 85 provides that "[a]nyone who has been the victim of unlawful arrest or detention shall have an enforceable right to compensation." "202 Chapter 10 of the ICC RPE sets out the rules and procedures related to this right of compensation. With respect to determining the proper amount of compensation, ICC RPE Rule 175 requires the competent Chamber to "take into consideration the consequences which the grave and manifest miscarriage of justice has had for the personal, family, social and professional situation of the person filing the request." 203

Rome Statute Article 55, Section 2 enumerates the rights of persons who are believed to have committed a crime within the jurisdiction of the Court. Those rights are triggered when such persons are "about to be questioned either by the Prosecutor, or by national authorities pursuant to a request" made by the Prosecutor. ${ }^{204}$ They include:

(a) The right to be informed, prior to being questioned, that there are grounds to believe the suspect committed a crime within the jurisdiction of the Court;

(b) The right to remain silent, without such silence being a consideration in the determination of guilt or innocence;

(c) The right to have legal assistance of the suspect's choosing, or, if the suspect does not have legal assistance, to have legal assistance assigned to him, in any case where the interests of justice so require, and without payment by the suspect in any case if the suspect does not have sufficient means to pay for it; and

(d) The right to be questioned in the presence of counsel unless the person has voluntarily waived his right to counsel. ${ }^{205}$

The person must be informed of these rights prior to being questioned. ${ }^{206}$ Consistent with these rights, ICC RPE Rule 112 requires that any questioning of the

\footnotetext{
201 Professor Zappalà argues that Article 55's "system of reference to other provisions reinforces the suggestion that there is a precise need to extend the right to legal assistance to all instances of arrest." Zappalà, supra note 3 , at 74 .

202 Id. art. 85.

203 ICC RPE, supra note 155, R. 175.

204 Rome Statute, supra note 154, art. 55.

205 Id.

206 Id. According to former U.S. Ambassador-At-Large for War Crimes Issues David J. Scheffer: "The Rome Statute includes a guarantee of a form of Miranda warning. In the United States, this right arises in cases of custodial interrogation. Under the jurisdiction of the ICC, the prosecutor must advise a person of his rights before he is questioned, whenever there are grounds to believe that he has committed a crime, even in non-custodial interrogations." David J. Scheffer, Advancing U.S. Interests with the International Criminal Court, 36 VAND. J. TRANSNAT'L L. 1567, 1572 (2003). Thus, the ICC is even more generous with respect to honoring a suspect's interrogation rights than the due process-friendly Miranda rules in the United States.
} 
suspect be audio or video-recorded. ${ }^{207}$ Furthermore, specific mechanisms for the implementation of the suspect's right to obtain evidence in his favor prior to trial were adopted in ICC RPE Rule $116{ }^{208}$ Finally, as an indirect means of enforcing these due process safeguards, the Statute contains the following two-pronged exclusionary rule in Article 69.7:

Evidence obtained by means of a violation of this Statute or internationally recognized human rights shall not be admissible if:

(a) The violation casts substantial doubt on the reliability of the evidence; or

(b) The admission of the evidence would be antithetical to and would seriously damage the integrity of the proceedings. ${ }^{209}$

\section{b. Trial Rights}

ICC trial proceedings are meant to ensure "full respect for the rights of the accused . .."210 The means for achieving this are found primarily in Articles 66 and 67 of the Rome Statute. Article 66 provides that "everyone" shall be presumed innocent until proved guilty before the Court in accordance with the applicable law. ${ }^{211}$ It also specifies the burden of proof by declaring that the onus is on the Prosecutor to prove the guilt of the accused. ${ }^{212}$ Finally, Article 66 spells out the standard of proof: in order to convict, the Court must be convinced of the guilt of the accused "beyond reasonable doubt."

Article 67 lays out a smorgasbord of additional trial-stage protections, including the right: (1) to a fair and impartial hearing; (2) to be informed promptly and in detail of the nature, cause and content of the charge, in a language which the accused fully understands and speaks; (3) to have adequate time and facilities for the preparation of the defense and to communicate freely with counsel of the accused's choosing in confidence; (4) to be tried without undue delay; (5) to be present at the trial; (6) to conduct the defense in person or through legal assistance chosen by the accused; (7) to be informed, if the accused does not have legal assistance, of this right; (8) to have legal assistance assigned by the Court in any case where the interests of justice so require, and without payment if the accused lacks sufficient means to pay for it; (9) to examine, or have examined, the witnesses against him and to obtain the attendance and examination of witnesses on his behalf under the same conditions as witnesses against him; (10) to raise defenses and present other evidence admissible under the Statute; (11) to have, if

${ }^{207}$ ICC RPE, supra note 155, R. 112.

${ }^{208}$ Id. R. 116.

209 Rome Statute, supra note 154, art. 69.7.

${ }^{210} I d$. art. 64 .

${ }^{211} I d$. art. 66.1.

${ }^{212}$ Id. art. 66.2.

${ }^{213}$ Id. art. 66.3. 
necessary, free of any cost, the assistance of a competent interpreter and such translations as are necessary to meet the requirements of fairness; (12) to remain silent and not to be compelled to testify or to confess guilt, without such silence being a consideration in the determination of guilt or innocence; (13) to make an unsworn oral or written statement in his defense; (14) not to have imposed on him any reversal of the burden of proof or any onus of rebuttal; (15) to have the Prosecutor disclose any evidence which tends to show the innocence of the accused, or to mitigate the guilt of the accused, or which may affect the credibility of prosecution evidence. ${ }^{214}$

Certain additional rights are scattered throughout the Statute. For example, a person may not be criminally responsible, unless the conduct in question constitutes, at the time it takes place, a crime within the jurisdiction of the Court (embodying the principle of nullum crimen sine lege). ${ }^{215}$ Similarly, a person convicted by the Court may be punished only in accordance with the Statute (and not by some other external means codifying the rule of nulla poena sine lege). ${ }^{216}$ In the same vein, no person may be criminally responsible for conduct prior to the entry into force of the Statute (enshrining the protection against ex post facto laws). ${ }^{217}$ Finally, the ICC, or any other court, may not try persons for conduct that formed the basis of crimes for which the persons have already been convicted or acquitted by the ICC (respecting the rule of ne bis in idem, which is more or less equivalent to the double jeopardy prohibition). ${ }^{218}$

Paralleling the ICTY and ICTR, another important right for the accused is to be tried by judges competent in criminal law/procedure and international law and who possess extensive experience in "a professional legal capacity." ${ }^{219}$ Moreover, any such judges must adequately represent the principal legal systems of the world, and reflect equitable geographic and gender representation. ${ }^{20}$ These judges must be independent in the performance of their functions and not engage in any activity that is likely to interfere with their judicial functions or to affect confidence in their independence. ${ }^{221}$ Article 41 provides a mechanism for defendants to request the disqualification of a judge whose impartiality may be reasonably doubted. ${ }^{222}$

With respect to sentencing, the ICC, like the ad hoc Tribunals, forbids the death penalty. ${ }^{223}$ Moreover, it also provides convicted defendants with a right to appeal. ${ }^{224}$ Although most of these rights are consistent with those accorded to suspects and

${ }^{214} I d$. art. 67.

Id. art. 22.

${ }^{216} I d$. art. 23.

${ }^{217}$ Id. art. 24.

${ }^{218} I d$. art. 20. The differences between ne bis in idem and double jeopardy will be discussed infra. Ne bis in idem is identical in significance to "non bis in idem." The two are used interchangeably in international instruments, court decisions, treatises and other materials.

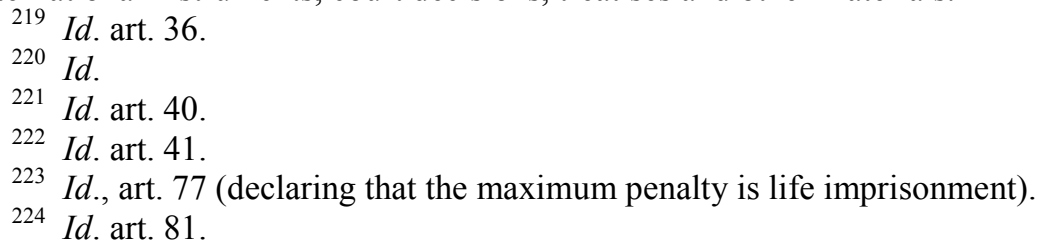


defendants in the ad hoc Tribunal systems, there are some important differences that will be highlighted below.

4. The Expansion of Rights Vis à Vis the Ad Hoc Tribunals

The relationship between the ICC prosecutor and judiciary provides significant insight into the ICC's superior due process treatment of defendants in comparison to the ad hoc Tribunals. As one commentator has noted, "the ICC prosecutor is overseen at every stage by the judiciary . .."225 This scrutiny, particularly during the investigative stage, helps ensure that the due process rights of suspect and accused are respected. For example, in contrast with the ad hoc Tribunals, the ICC requires that the prosecutor seek confirmation of a judge before the provisional arrest of a suspect. ${ }^{226}$ Moreover, the "organ of justice" role of the ICC prosecutor, as defined in Rule 54 of the Rome Statute, provides another structural layer of due process protection not found in the more adversarial setting of the ad hoc Tribunals. These structural innovations move the ICC past the ad hoc Tribunals on the fairness spectrum, opposite Nuremberg's perceived "victor's justice."227

Certain specific provisions in the ICC system have the same effect. For example, Article 16 allows the Security Council to suspend an investigation for twelve months with the option of renewing the suspension indefinitely. This mechanism within the Statute (apart from, and in addition to, the powers exercised by the Pre-Trial Chamber) could be used, for example, to derail an illegitimately motivated investigation or one that resulted in serious due process violations. There is no such check on the prosecutor's powers in the ad hoc Tribunal system.

Moreover, the ICC's Article 55 rights of "persons during an investigation" include an explicit right not to be subject to unlawful or arbitrary arrest as well as a right not to be subject to "coercion, duress or threat, to torture or to any other form of cruel, inhuman or degrading treatment." 228 The Statutes and RPEs of the ad hoc Tribunals omit reference to any such right. ${ }^{229}$

Consistent with the above-mentioned Article 55 rights, Article 59 of the Rome Statute hints at a stronger degree of agency between the ICC and States cooperating in arrest and detention by labeling the latter as "custodial States." 230 Under the Rules of the

225 Amy Powell, Three Angry Men: Juries in International Criminal Adjudication, 79 N.Y.U. L. REV. 2341, 2362 (2004).

226 Rome Statute, supra note 154, art. 58.

227 Leila Nadya Sadat, The Legacy of the ICTY: The International Criminal Court, 37 NEW ENG. L. REV. 1073, 1077 (2003) (indicating the ICC will avoid the perception of "victor's justice.”).

228 Rome Statute, supra note 154, art. 55.1.d.

229 See Sluiter, supra note 4, at 936 ("An important omission [from the Statutes and Rules of the ad hoc Tribunals] is the right not to be subjected to arbitrary arrest and detention, as contained in Article 9 of the ICCPR.”).

${ }^{230}$ Rome Statute, supra note 154, art. 59. See also Defrancia, supra note 4, at 1408. 
ad hoc Tribunals, however, the supervisory responsibilities of the Tribunal do not attach until "the moment of . . . transfer (to actual custody of the Tribunal).,"231

Similarly, Article 85 of the Rome Statute recognizes a degree of ICC "cradle-tograve supervisory power" 232 by granting an "enforceable right to compensation" 233 for anyone who has been the victim of unlawful arrest or detention. ${ }^{234}$ Once again, there is no comparable provision in the statutes or rules of the ad hoc Tribunals. ${ }^{235}$

Another important ICC procedural safeguard is the right of the suspect, pursuant to Rome Statute Article 61, to participate with counsel in the indictment confirmation hearing. The ad hoc Tribunals, adhering to a model of ex parte indictment review, provide for no such participation.

Further, "in the ICC Statute the protection of the presumption of innocence is definitely more clearly organized [than the equivalent for the ad hoc Tribunals] and the provisions of the Statute take into account the multifaceted aspects of the presumption . . "236 In particular, Article 66 of the Rome Statute states that everyone shall be presumed innocent until proved guilty." 237 The use of the term "everyone" stretches the presumption to cover more than just the accused. ${ }^{238}$ Moreover, the impact of the presumption has a ripple effect on evidentiary matters in the ICC. Article 67.1(i) states that no reversal of the burden of proof is admissible. According to Professor Zappalà:

This is a major breakthrough because in the system of the ad hoc

Tribunals there are reversals that virtually require a probatio diabolica. Instances of this are: proof that the confession was forced (Rule 92 RPEs) or the burden being placed on the accused to prove that circumstances exist that may justify provisional release established in Rule 65 of both RPEs. ${ }^{239}$

Finally, absent in the statutes and rules of the ad hoc Tribunals, the accused on trial before the ICC have "the right to make an unsworn oral or written statement in his/her defense."

231 ICTR RPE, supra note 99, R. 40(C); See also Defrancia, supra note 4, at 1404.

232 Defrancia, supra note 4, at 1404.

233 Rome Statute, supra note 154, art. 85.

234 Id.

235 On September 19, 2000, then-ICTY President Claude Jorda submitted a letter to the UN Secretary General, on behalf of all ICTY judges, asking the Security Council to consider amending the ICTY Statute to enable the Tribunal to award compensation to persons who have been wrongly prosecuted or convicted by it, as well as unlawfully arrested or detained under its authority. Seven days later, his ICTR counterpart, Navanethem Pillay, sent a virtually identical letter to the Secretary General. The Security Council did not comply with the requests of the ad hoc Tribunal presidents. See Beresford, supra note 108, at 629, 645.

236 Zappalà, supra note 3, at 94.

237 Rome Statute, supra note 154, art. 66 (emphasis added).

238 Zappalà, supra note 3 , at 94 .

239 Id. 
Overall, then, the ICC represents a great leap forward in the due process evolution of international criminal procedure. But it does not encompass the full panoply of protections afforded to defendants in the most rights-protective national systems. The reasons for this will be explored in the following section.

\section{FORCES LIMITING DUE PROCESS IN INTERNATIONAL CRIMINAL PROCEDURE}

From the London Charter to the Rome Statute, the community of nations has gradually woven together a procedural safety net for those accused in transnational courts of participating in large-scale, systematic violence. That safety net, cast widely over the constituent instruments of international justice, is in certain respects too porous to preserve the full complement of due process rights owed to suspected war criminals and genocidaires. The reality of global criminal prosecution, unfortunately, is often much too messy and complex for the best-intentioned due process schemas hatched by treaty negotiations and committee meetings. ${ }^{240}$ Those efforts may be stymied by three recurring phenomena unique to international criminal prosecution: (1) the fragmentation of enforcement over two or more jurisdictions; (2) the integration of two distinct, and often contradictory, legal systems - the common law and the civil law; and (3) the extreme gravity of the crimes involved.

\section{A. Fragmentation}

As distinct from national criminal procedure systems, international criminal procedure is "fragmented" between and among multiple jurisdictions.",241 For example, while an international tribunal may issue an arrest warrant, that warrant will be executed by a sovereign national jurisdiction. That sovereign may then detain and question the suspect before he is transferred to the jurisdiction of the international court. Yet another sovereign may conduct searches and collect evidence to be used in prosecuting the suspect. Despite its best due process intentions, an international tribunal has limited control, if any, over the manner in which these searches are conducted or in which the suspect is arrested, detained or questioned. ${ }^{242}$ As a result, "the disjunction between authority and control, common to international institutions, is too great to allow for consistently fair criminal adjudication.",243

\footnotetext{
${ }^{240}$ See Bassiouni, supra note 6, at 486 ("It should be remembered that the drafting of the [Rome] statute was essentially a diplomatic exercise ... The diplomatic pragmatism that characterizes many provisions of the Statute is simply not the generally accepted legislative approach of many national legal systems."). Andrew J. Walker, When a Good Idea Is Poorly Implemented: How the International Criminal Court Fails to Be Insulated from International Politics and to Protect Basic Due Process Guarantees, 106 W. VA. L. REV. 245, 277 (2004) ("Most of the diplomats who worked on the [Rome] statute 'lacked expertise in international criminal law, comparative criminal law, or comparative criminal procedure[,]' and 'had no criminal practice experience of any kind."').

${ }^{241}$ Sluiter, supra note 4, at 942.

242 Id.

243 Jacob Katz Cogan, International Criminal Courts and Fair Trials: Difficulties and Prospects, 27 YALE J. INT'L L. 111, 116 (2002).
} 


\section{Search and Seizure}

With respect to searches and seizures, fragmentation could lead to the trampling of privacy rights by sovereign nationals. The Rome Statute, for example, affords the ICC, through Article 99(4), only very limited powers to conduct on-site investigations. ${ }^{244}$ "This entails that intrusive measures, such as searches and seizures will have to be executed by the State Party upon request by the ICC." This could open the door to serious due process issues because the Rome Statute does not contain any express language providing for a search and seizure right to privacy. ${ }^{245}$ Thus "U.N. troops, national police, governmental agents, or civilian vigilantes" could "ignore the privacy interests of suspects or accused persons ... in the perceived greater interest of promoting justice and eradicating impunity for heinous crimes . .."246 Moreover, any evidence obtained from such searches could be admissible because "the ICC statute does not permit investigation into how a state collects evidence brought before the court . .."247

\section{Arrest and Detention}

In the same spirit, this reliance on external agents can compromise the due process rights of international criminal defendants with respect to arrest and detention. As explained supra, the ad hoc Tribunals provide for the provisional arrest of suspects by States. The Prosecutor may directly request a State to arrest a suspect on the standard that there are "grounds to believe" that the suspect "may have committed a crime over which the Tribunal has jurisdiction." 248 The rights of the suspect include the right to counsel and the right to remain silent. ${ }^{249}$

In a string of decisions ruling on defense motions for release, the International Criminal Tribunal for Rwanda has consistently held that the Tribunal has "no jurisdiction over the conditions of any arrest, detention or other measures carried out by a sovereign State at the request of the Tribunal."250 This has resulted in questionable due process jurisprudence.

\footnotetext{
244 Rome Statute, supra note 154, art. 99(4).

245 See George E. Edwards, International Human Rights Law Challenges to the New International Criminal Court: The Search and Seizure Right to Privacy, 26 YALE J. INT'L L. 323, 327 (2001).

246 Id. at 333.

247 Walker, supra note 240, at 281. In one case, however, the ICTY found that a statement obtained from the accused in the absence of his counsel could not be admitted into evidence. Before being transferred to the ICTY, the accused, Zdrako Mucic had been interrogated by Austrian police. The interrogation was not conducted at the behest of the ICTY, but with a view to Mucic's surrender to the ICTY or extradition to a State. Under Austrian law, there is no right for counsel to be present at this type of interrogation. In opposing Mucic's request to exclude the evidence, the Prosecutor contended that the Tribunal itself, including its organs, had not violated the right to counsel, as protected by the ICTY RPE and international human rights instruments, and as a result, there was no reason to exclude the evidence. The Trial Chamber, however, ruled that the exclusion of evidence obtained in violation of internationally protected human rights is mandatory under rule 95. See Prosecutor v. Delalic, et al., Case No. IT-96-21-T, Decision on Zdravko Mucic's Motion for the Exclusion of Evidence, (Sept. 2, 1997).

248 ICTR RPE, supra note 99, R. 40 bis.

249 Id. R. 42.

250 Prosecutor v. Rwamakuba, Case No. ICTR-98-44-T, $\mid 22$ (Dec. 12, 2000). See also Prosecutor v. Nzirorera, Case No. ICTR-98-44-T (Sept. 7, 2000) (where defendant complained he was arbitrarily
} 
In Prosecutor v. Kajelijeli, for example, Benin authorities arrested the defendant and placed him in custody on June 5, 1998. ${ }^{251}$ At the time of his arrest, the defendant happened to be at the residence of Joseph Nzirorera, a former Rwandan government official accused of organizing atrocities in Rwanda's Ruhengeri province. The Benin authorities were attempting to execute an ICTR arrest warrant on Nzizorera. The authorities presumably did not know who Kajelijeli was -- they did not have a search warrant for him. ${ }^{252}$

On September 9, 1998, the defendant, who had been the mayor of Rwanda's Mukingo commune (part of the Ruhengeri province) at the time of the 1994 genocide, was transferred from Benin to the seat of the Tribunal in Arusha, Tanzania. ${ }^{253}$ It was not until approximately five months later, on February 2, 1999, that he was assigned defense counsel. $^{254}$ Finally, the defendant initially appeared for arraignment before a Trial Chamber on April 7, 1999 - roughly seven months after being transferred to the ICTR. ${ }^{255}$

On November 9, 1998, the defendant filed a motion challenging the legality of his arrest and detention. In his motion, he contended that the ICTR did not have jurisdiction over him, in part, because of alleged irregularities in his arrest and detention in Benin. ${ }^{256}$ In particular, he argued that: (1) he had been arbitrarily arrested and detained; (2) when he was arrested on June 5, 1998, he was not informed of the reasons for his arrest; (3) he was detained in Benin for three months without learning the charges against him and without being charged; and (4) before his transfer to the ICTR, he was handed three documents, two of which were in language he neither spoke nor understood, and the third was redacted as to him, so it could not provide him with any notice, let alone adequate notice, of the charges against him.

In dismissing Kajelijeli's motion, the Tribunal focused on the fact that it lacked control over actions carried out by law enforcement officials in Benin:

When the Prosecutor makes a request for the arrest of the Accused, the matter falls within the domain of the

detained for more than one month because he was not promptly informed of the reasons for his arrest, Tribunal lacks jurisdiction to review the legal circumstances attending the arrest of the suspect insofar as the arrest was made pursuant to the laws of the arresting state); Prosecutor v. Kajelijeli, Case No. ICTR-9844-I, ๆ 35 (May 8, 2000) [hereinafter Kajelijeli Decision]; Prosecutor v. Karemera, Case No. ICTR-98-441 (Dec. 10, 1999) (holding the Tribunal "cannot provide any remedy concerning such arrest and custody as these are still matters within the jurisdiction of the requested State.”); Prosecutor v. Ngirumpatse, Case No. ICTR-97-44-1 (Dec. 10, 1999) (concluding "the Tribunal is not competent to supervise the legality of arrest, custody, search and seizure executed by the requested State. The laws of the requested State may not require an arrest warrant or impose other legal conditions.").

251 See Kajelijeli Decision, supra note 250, \ 35.

252 Id.

253 Id.

254 Id.

255 Id.

256 See Sherrie L. Russell-Brown, Poisoned Chalice?: The Rights of Criminal Defendants under International Law, During the Pre-Trial Phase, 8 UCLA J. INT'L L. \& ForEIGN AFF. 127, 134 (2003). 
requested State and it is that State which organizes, controls and carries out the arrest in accordance with their domestic law. All these procedures were fulfilled in this case . . the Trial Chamber therefore, considers that it cannot provide any remedy concerning such arrest and custody as these are still matters within the jurisdiction of the requested State . . . the Tribunal is not competent to supervise the legality of arrest, custody, search and seizure executed by the requested State. The laws of the requested State may not require an arrest warrant or impose other legal conditions. $^{257}$

The Kajelijeli case is by no means unique. Perhaps the best known of these cases is Prosecutor v. Barayagwiza. ${ }^{258}$ Jean-Bosco Barayagwiza was a founding member of the extremist Hutu-power party Coalition for the Defense of the Republic (CDR) and the infamous Radio Télévision Libre des Mille Collines (RTLM), often called "Radio Machete.",259

On April 15, 1996, Barayagwiza, along with a number of other Rwandans, was arrested in Cameroon pursuant to international arrest warrants issued by Rwanda and Belgium. ${ }^{260}$ The next day the ICTR Prosecutor also requested that Barayagwiza be held pending the Tribunal's decision as to whether it would request his transfer to the ICTR seat in Arusha. ${ }^{261}$ On May 16, 1996, however, the ICTR Prosecutor notified Cameroon that it was no longer interested in Barayagwiza's transfer. ${ }^{262}$ On February 17, 1997, Cameroon denied Rwanda's extradition request and ordered Barayagwiza's release. ${ }^{263}$ At the same time, however, the ICTR Prosecutor again asked that Barayagwiza be held and a week later officially requested his transfer. ${ }^{264}$ Cameroon promptly issued a transfer order on March 4, but did not send Barayagwiza to Arusha until November 19, $1997 .{ }^{265}$

On February 23, 1998, he pleaded not guilty to all counts lodged against him. The next day, February 24, 1998, Barayagwiza filed an "extremely urgent motion" that sought

257 Kajelijeli Decision, supra note 250, ๆ $34-35$.

258 Prosecutor v. Barayagwiza, Case No. ICTR-97-19-AR72, Appeals Chamber Decision (Nov. 3, 1999) [hereinafter Barayagwiza I]. See also Prosecutor v. Barayagwiza, Case No. ICTR-97-19-A, Appeals Chamber Decision on Prosecutor's Request for Review or Reconsideration (Mar. 31, 2000) [hereinafter Barayagwiza II].

259 See generally Gregory S. Gordon, “A War of Media, Words, Newspapers, and Radio Stations”: The ICTR Media Trial Verdict and a New Chapter in the International Law of Hate Speech, 45 VA. J. INT'L L. 139, 140-41 n.2 (2004).

${ }^{260}$ Barayagwiza I, supra note 258. See also William A. Schabas, Barayagwiza v. Prosecutor, 94 AM. J. INT'L L. 563 (2000); Mercedeh Momeni, Why Barayagwiza Is Boycotting His Trial at the ICTR: Lessons in Balancing Due Process Rights and Politics, 7 ILSA J. INT’L \& COMP. L. 315 (2001).

261 Barayagwiza I, supra note 258.

262 Id.

263 Id.

264 Id.

265 Id. 
to throw out his arrest because, inter alia, he had been illegally detained. ${ }^{266}$ The ICTR Trial Chamber denied the motion. ${ }^{267}$

However, on November 3, 1999, the Appeals Chamber reversed the Trial Chamber decision based on "abuse of process" and ordered that Barayagwiza be returned to Cameroon because the length of his detention had been far beyond what international human rights standards allow. ${ }^{268}$ The Appeals Chamber inveighed that "[n]othing less than the integrity of the Tribunal is at stake in this case. Loss of public confidence in the Tribunal, as a court valuing human rights of all individuals--including those charged with unthinkable crimes--would be among the most serious consequences of allowing [Barayagwiza] to stand trial in the face of such violations of his rights."269

On November 19, 1999, the Prosecutor notified the Appeals Chamber of her intention to ask it to review or reconsider its ruling, and she submitted such a motion on December 1, citing new facts. ${ }^{270}$ The "new facts" consisted, in part, of a Cameroonian judge's explanations of the politics of the transfer process from Cameroon to Arusha. ${ }^{271}$ On March 31, 2000, the Appeals Chamber ruled that because the new facts showed that "the violations suffered by the [Accused] and the omissions of the Prosecutor are not the same as those which emerged from the facts on which the [November] Decision is founded," the November decision should be "altered."272 The gravamen of the Appeals Chamber decision in Barayagwiza II was "the new information [that] the violations of Barayagwiza's rights were more due to Cameroon than the Prosecutor . .."273 In the end, Cameroon's falling on the sword had no consequences for Cameroon but entailed a serious derogation of Barayagwiza's due process rights. ${ }^{274}$

$266 I d$.

267 See Prosecutor v. Barayagwiza, Case No. ICTR-97-19, Decision on the Extremely Urgent Motion by the Defense for Orders to Review and/or Nullify the Arrest and Provisional Detention of the Suspect (Nov. 17, 1998).

268 Barayagwiza I, supra note 258.

269 Id. $\ 112$.

270 See Prosecutor v. Barayagwiza, Case No. ICTR-97-19, Decision on Prosecutor's Request for Review or Reconsideration (Mar. 31, 2000).

271 Id. See also Momeni, supra note 260, at 319.

272 Barayagwiza II, supra note 258, at 974.

273 Sluiter, supra note 4, at 944. It should be pointed out that after Barayagwiza I, Rwanda suspended cooperation with the ICTR, thereby effectively halting all of the Tribunal's investigations. See Katz Cogan, supra note 243, at 135. The ICTR Appeals Chamber judges denied that they had been coerced into changing their decision to release Barayagwiza, but most commentators believe it likely that "Rwanda's threats played a part in the outcome." Id. Barayagwiza was eventually tried and convicted of genocide, direct and public incitement to commit genocide, conspiracy to commit genocide, and crimes against humanity (extermination and persecution). He was sentenced to life imprisonment but, in light of the procedural violations related to his pre-trial detention, his sentence was reduced to thirty-five years. See Gordon, supra note 259, at 141.

274 As a remedy for the due process violations, Barayagwiza's sentence was reduced from life imprisonment to 35 years. Gordon, supra note 259, at 141 n. 3. 
The ICTY has faced similar issues and arrived at the same result. In Prosecutor v. Nikolic, ${ }^{275}$ the defendant, the former commander of the Susica detention camp in Eastern Bosnia, claimed that his arrest and subsequent detention were unlawful because he was abducted by unknown individuals from the territory of the Federal Republic of Yugoslavia (in Serbia) and then placed in the custody of the ICTY's "special police force" (SFOR) in Bosnia. ${ }^{276}$ He claimed he was handcuffed and in the trunk of a car when handed over to SFOR ${ }^{277}$ and that SFOR had actual or constructive knowledge of the abduction. ${ }^{278}$ In a motion challenging the exercise of the Tribunal's jurisdiction, the defendant requested the remedy of terminating the proceedings. ${ }^{279}$ The Chamber denied the motion on the grounds that, inter alia, neither the Tribunal nor SFOR were involved in, or had actual or constructive knowledge of, the defendant's abduction. ${ }^{280}$

\section{Defense Efforts to Collect Evidence}

If international criminal prosecutors must surmount sizable obstacles to obtain all necessary cooperation with States, the defendants they prosecute are truly disadvantaged in this regard. State reluctance to assist suspected war criminals and genocidaires is exacerbated by statutory mechanisms permitting States to eschew the cooperation regime.

For example, ICTY Statute Article 29 provides that "States shall cooperate with the International Tribunal in the investigation and prosecution of persons accused of committing serious violations of international humanitarian law." ${ }^{281}$ Under ICTY RPE Rule 39, the Prosecutor may summon and question witnesses and may seek the assistance of any State in doing so. ${ }^{282}$ Rule 54 permits judges to "issue such orders, summonses, subpoenas, warrants, and transfer orders as may be necessary for purposes of an investigation or for the preparation or conduct of trial." 283

Nevertheless, the ICTY RPE help to neuter these provisions by creating loopholes for national security information (Rule 54 bis) and materials provided to the ICTY on a confidential basis (Rule 70). ${ }^{284}$ The same is true of the ICC. Article 86 of the Rome Statute provides that "States Parties shall, in accordance with the provisions of this Statute, cooperate fully with the Court in its investigation and prosecution of crimes within the jurisdiction of the Court." On the other hand, under Article 54.3(e), materials provided to the Court "on the condition of confidentiality" may not be disclosed. ${ }^{285}$ Similarly, pursuant to Article 72, a State may refuse to disclose evidence if doing so

275 Prosecutor v. Nikolic, Case No. IT-94-2-PT, Decision on Defense Motion Challenging the Exercise of Jurisdiction, (Oct. 9, 2002).

$276 I d$. 21 . SFOR was only authorized to operate in Bosnia.

277 Id.

278 Id. $\ 32$.

279 Id. 1 \ 23-24.

280 Id. 9967 . The Chamber also found that the manner in which the accused was abducted did not amount to serious mistreatement. Id., ๆ 114.

281 ICTY Statute, supra note 94, art. 25.

282 ICTY RPE, supra note 94, R. 39.

283 Id. R. 54.

284 Id. RR. 54 bis \& 70.

285 ICTY Statute supra note 94, art. 54.3(e). 
would "prejudice its national security interests." 286 The defendant's inability to collect such information may also go a long way toward curtailing his due process rights.

The ICTY case of Prosecutor v. Blaskic is illustrative. ${ }^{287}$ Tihomir Blaskic, a Bosnian Croat, had been a colonel and then a general in the Croation Defense Council (or "HVO," the Bosnian Croat army). ${ }^{288}$ In the spring of 1993, HVO forces engaged in ethnic cleansing measures that resulted in the massacre of Muslim civilians in the central Bosnian Lasva Valley region -- most infamously in the village of Ahmici. ${ }^{289}$ Blaskic was the commander of the HVO's Central Bosnia Operative Zone at the time. ${ }^{290}$ On November 10, 1995, the ICTY indicted Blaskic (relying on the command responsibility doctrine) for crimes against humanity, grave breaches of the Geneva Conventions of 1949, and violations of the laws or customs of war. Blaskic surrendered himself to the Tribunal in $1996 .^{291}$

On January 15, 1997, the ICTY issued subpoenas duces tecum to, inter alia, the Republic of Croatia, its Defense Minister, as well as to its Custodian of Records of the Central Archives. ${ }^{292}$ The subpoenas ordered the State and its officials to produce documents concerning the military command structures and plans of military actions. ${ }^{293}$ The matter was brought before Trial Chamber II, which found that ICTY judges had authority to issue orders, such as subpoenas, to States, high government officials and individuals. $^{294}$ Croatia appealed and on October 29, 1997, the Appeals Chamber ruled to quash the subpoena. ${ }^{295}$ In doing so, it defined the scope of the ICTY's judicial reach in relation to sovereign States. While it held that the ICTY could issue binding orders to States, ${ }^{296}$ it also found that it could not issue binding orders to specific State officials acting in their official capacity. ${ }^{297}$ It further held that the ICTY has no enforcement powers in relation to States. ${ }^{298}$ Rather, its only recourse is to report such non-compliance to the Security Council. ${ }^{299}$ Finally, the Appeals Chamber ruled that States could invoke a "national security" justification for withholding evidence. ${ }^{300}$

\footnotetext{
286 Id. art. 72.

287 Prosecutor v. Blaskic, Judgment, Case No. IT-95-14-T (Mar. 3, 2000) [hereinafter Blaskic Trial Judgment].

$288 \mathrm{Id}$.

289 Id.

290 Id.

291 Id.

292 Prosecutor v. Blaskic, Case No. IT-95-14-PT, Decision on the Objection of the Republic of Croatia to the Issuance of Subpoenae Duces Tecum, (Jul. 18, 1997) [hereinafter Blaskic Trial Chamber Subpoena Decision].

293 Id.

294 Id

295 Prosecutor v. Blaskic, Case No. IT-95-14-AR108bis, A. Ch., Judgment on the Request of the Republic of Croatia for Review of the Decision of Trial Chamber II of 18 July 1997, (Oct. 29, 1997) [hereinafter Blaskic Appeal Chamber Judgment].

296 Id. $₫$ ब 26-31.

297 Id. 9 ब $38-45$.

298 Id. 9 ๆ 33-37.

299 Id.

$300 I d$. 967 . However, the Appeals Chamber found that it was for ICTY judges to determine whether the justification was valid, which might be done through in camera ex parte scrutiny. Id., 98 . The appeals
} 
Blaskic was eventually tried, convicted and sentenced to 45 years' imprisonment. $^{301}$ Only a few days later, Croatian authorities announced they had found documents that may have exonerated him. ${ }^{302}$ These documents had come to light after the death of Croatian president Franjo Tudjman, who had opposed disclosing documents in connection with the Blaskic proceedings. ${ }^{303}$ On March 17, 2000, Blaskic filed a notice of appeal and ultimately submitted 8,000 pages of additional evidence to the Appellate Chamber. ${ }^{304}$ On July 29, 2004, based in part on the new evidence obtained from Croatia, the Appeals Chamber reversed 16 of the Trial Chamber's 19 convictions and reduced Blaskic's sentence to nine years' imprisonment. ${ }^{305}$ Thus, the Blaskic case perfectly demonstrates fragmentation's potential for pernicious effects on due process in the pretrial stage.

\section{Compelling Witness Testimony}

In addition to documentary evidence, international defendants may also face troublesome obstacles in securing the presence of favorable witnesses at trial. Pursuant to the Rome Statute, for example, "States Parties are under no duty to compel witnesses to appear in the Hague to testify at trial."306 Under Rule 93(1)(e) of the Rome Statute, the duty of States is limited to the facilitation of the voluntary appearance of a person as a witness. $^{307}$

Some observers have gone so far as to posit a right of witnesses not to appear before the ICC. ${ }^{308}$ Under this provision, a person in custody in the requested State may be transferred to the ICC only if that person freely consents to the transfer. These observers argue that if the person's transfer to the ICC's custody hinges on that person's consent, then, by extrapolation, the same must be true for all other witnesses. ${ }^{309}$

chamber set forth certain guidelines for such scrutiny but left the development of the exact procedures to the trial chambers. Id., ๆๆ 68, 69. See also Herwig Roggemann, National Security and Protection of the State in National and International Criminal Procedure: Systematic and Comparative Aspects, in Roggemann, supra note 11, at [hereinafter National Security]; Sean D. Murphy, Progress and Jurisprudence of the International Criminal Tribunal for the Former Yugoslavia, 93 AM. J. INT'L L. 57, 8183 (1999).

301 Blaskic Trial Judgment, supra note 287.

${ }^{302}$ Katz Cogan, supra note 243, at 122.

${ }^{303} I d$.

304 See Prosecutor v. Blaskic, Case No. IT-95-14-A Judgment Appeal (Mar. 3, 2000) [hereinafter Blaskic Trial Judgment Appeal]; Mark A. Drumbl, ICTY Appeals Chamber Delivers Two Major Judgments: Blaskic and Krstic, American Society of International Law Insights (Aug. 2004), available at http://www.asil.org/insights/insigh143.htm.

${ }^{305}$ Drumbl, supra note 304.

${ }^{306}$ Kress, supra note 182, at 616.

307 Rome Statute, supra note 154, art. 93(1)(e). This principle of voluntary appearance of witnesses before the ICC conflicts with Article 69(2)'s dictate that the testimony of a witness shall be given in person. See Kress, supra note 182, at 616. Moreover, "the legal framework of the Ad Hoc Tribunals have not adopted the principle of voluntary of appearance." See Sluiter, supra note 10, at 254.

308 See, e.g. Sluiter, supra note 10, at 254.

309 See id.; Kress, supra note 182, at 616. Kress contends, however, that this interpretation of Article 93(7) runs directly counter to Article 64(6)(b), which empowers the Trial Chamber to "require the 
Overall, then, international defendants must rely on the kindness of strangers (i.e. States) for fairness in the way they are searched, seized, detained, notified of the charges against them, provided with counsel (if at all), transferred to an international court for arraignment and given access to witnesses, documents and other possible exculpatory evidence. Such kindness is often lacking and this is an inherent constraint on the application and growth of due process in international criminal procedure. ${ }^{310}$

\section{B. Integration}

The second inhibiting factor, "integration," refers to the efforts of international criminal procedure to harmonize the differing rules of its member countries into a cohesive system that will satisfy all concerned. As pointed out earlier, the primary tension in this regard is between two legal systems: the Anglo-American common law system versus the civil law system, which predominates in continental Europe. Because civil law systems place "more limitations on the rights of defendants" than do common law systems, ${ }^{311}$ compromises made to appease civil law practitioners may result in constricting the rights of defendants that are cherished as fundamental by common law jurists.

This phenomenon, as demonstrated previously, certainly played a role in the diminution of due process rights at Nuremberg. But six decades on, after the blossoming human rights movement has reached full flower, what fundamental prerogatives have been dispensed with in deference to continental practice? In contrast to the "fragmentation" phenomenon (primarily affecting pre-trial matters), the impact of integration is seen mostly in the trial and post-trial stages. A derogation of rights comes into focus primarily with respect to three areas: (1) permitting the functional equivalent of trials in absentia; (2) permitting the admission of evidence through other than live witness testimony; and (3) exposing defendants to the perils of double jeopardy.

attendance and testimony of witnesses.” Id; Rome Statute, supra note 154, art. 64(6)(b). According to Kress, this Article "clearly implies an international obligation upon witnesses to comply with a request of the Trial Chamber to appear." Kress, supra, note 182, at 616.

310 See generally, William A. Schabas, National Security Interests and the Rights of the Accused, in National Security, supra note 300. As mentioned supra, however, international courts can at least provide monetary awards to defendants deprived of due process. They can also exclude evidence obtained through, or in connection with, such deprivations.

${ }^{311}$ Martha Kimes, The Effect of Foreign Criminal Convictions under American Offender Statutes: A Case Against the Use of Foreign Crimes in Determining Habitual Criminal Status, 35 Colum. J. TRANSNAT'L L. 503, 525 n.123 (1997). See also, Cassese, supra note 15, at 383. This is true even in completely different forums such as international athletic doping cases. See Michael S. Straubel, Doping Due Process: A Critique of the Doping Control Process in International Sport, 106 DICK. L. REV. 523, 544 ("Although much of the international conflict over doping control is the result of a clash between United States common law notions of due process on the one side and civil law notions of due process on the other side, United States standards of procedural due process offer the most protection to an accused athlete."). 


\section{The Functional Equivalent of Trials in Absentia}

Under the ICTY RPE, the first step toward trial is the Prosecutor's submission of an indictment for confirmation by a judge. ${ }^{312}$ After a review hearing and confirmation of the indictment, a warrant, sent to the relevant States, is issued for the accused's arrest. ${ }^{313}$ The Prosecutor may also request, through the ICTY Registrar, that the national authorities of the relevant States publish the indictment in widely circulated newspapers.

In cases where these measures fail to bring about the arrest of the accused, the Tribunal may resort to Rule 61, which sets out the "Procedure in Case of Failure to Execute a Warrant." There are essentially two steps in the Rule 61 procedure. The first step requires the Prosecutor to satisfy the confirmation judge that the Prosecutor has taken all reasonable steps to effect personal service. After this begins the second step in the procedure, known as the Rule 61 hearing. At this stage, the Prosecutor must submit the indictment and supporting evidence, which may include witness testimony, to the Trial Chamber in open court. ${ }^{315}$ If, on the basis of the above evidence "together with such additional evidence as the Prosecutor may tender," the Trial Chamber is satisfied that "there are reasonable grounds for believing that the accused has committed all or any of the crimes charged in the indictment, it shall so determine." ${ }^{316}$ In addition, the Chamber will issue an international arrest warrant for the accused ${ }^{317}$ and may order a State to provisionally freeze the accused's assets. ${ }^{318}$

In his opening statement at the Tribunal's first Rule 61 hearing against Dragan Nikolic, Justice Richard Goldstone, the former Prosecutor of the Tribunal, asserted that such proceedings have important consequences: "The publication of the evidence before the Tribunal ... will constitute a permanent judicial record for all time of the horrendous war crimes that have been committed in the former Yugoslavia. That public record will assist in attributing guilt to individuals ... .,319

${ }^{312}$ ICTY RPE, supra note 94, R. 47(A).

${ }^{313} I d$. R.R. 55, 56, 58 \& 59.

314 Id. R. 60.

${ }^{315}$ Id. R. 61(E).

${ }^{316}$ Id. R. $61(\mathrm{C})$.

${ }^{317}$ Id. R. 61(D).

318 Id. If the Chamber is satisfied that "the failure to effect personal service was due in whole or in part to a failure or refusal of a State to cooperate with the Tribunal in accordance with Article 29 of the Statute [it] shall so certify." Id, R. 61(E). The certification may trigger notification to the United Nations Security Council of the State's failure or refusal to cooperate with the Tribunal. Id.

${ }_{319}$ Prosecutor v. Nikolic, Case No. IT-94-2-I (Oct. 9, 1995) (Goldstone, J., opening statement). Nikolic was a Bosnian Serb commandant of the Susica Detention Center in the Vlasenica region of Bosnia Herzegovina. Id. On 4 November 1994, Nikolic became the first person to be indicted by the ICTY. He was arrested on April 20, 2000 by the SFOR in Bosnia Herzegovina and immediately transferred to the ICTY, on April 21, 2000. See Prosecutor v. Nikolic, Judgment, Case No. IT-94-2-A (Feb. 4, 2005). On September 4, 2003, Nikolic pled guilty to several counts of crimes against humanity. Id. After appealing his sentence as decided by the Trial Chamber, the Appeals Chamber sentenced him to twenty years' imprisonment on February 4, 2005. Id. 
In light of this rationale for Rule 61 hearings, they have been "characterized as the functional equivalent of trials." 320 In this sense, Rule 61 "protects the interests of the civil law countries [in trials in absentia] because a civil law inquisitorial method was adopted in the procedure which allows a Trial Chamber at the ICTY to examine and question witnesses and pronounce whether there is reason to believe the suspect committed the crimes specified in the indictment." 321 According to Professor William Schabas, "They [Rule 61 proceedings] really were in absentia trials, the only meaningful distinction being they didn't impose a sentence when it was over."322

As a result, "many believe [this form of trial in absentia] does not comport with the norms of due process under the international human rights regime." 323 Of the laundry list of due process violations defendant's absence entails, perhaps the most egregious is the inability to cross-examine witnesses. ${ }^{324}$ Less obvious, perhaps, is the proceeding's standard of proof. At the end of the hearing, as noted above, the judges state whether there are mere "reasonable grounds" to believe the accused has committed the acts charged in the indictment. ${ }^{325}$ This finding has been described as "a determination of guilt." 326 Thus, "reasonable grounds" is certainly an anemic standard of proof in contrast to the robust "beyond a reasonable doubt" standard prevailing in customary rightsprotective criminal adjudications. ${ }^{327}$

Regrettably, the potential for such pre-trial kangaroo courts exists at the ICC as well. As explained previously, Article 61(2) of the ICC RPE allows the Pre-Trial Chamber to conduct confirmation hearings in the absence of the person charged. ${ }^{328}$ This occurs when it is not possible to find the person charged in spite of reasonable steps taken

320 Mark Thieroff \& Edward A. Amley, Jr., Proceeding to Justice and Accountability in the Balkans: The International Criminal Tribunal for the Former Yugoslavia and Rule 61, 23 YALE J. INT'L L. 231, 234 (1998). These proceedings were conducted on a fairly regular basis in the early years of the ICTY. Several ICTY defendants have been the subject of Rule 61 hearings, including Radovan Karadzic and Radko Mladic. See Anne L. Quintal, The "Voice of the Victims” Screams out for Justice, 36 COLUM. J. TRANSNAT'L L. 723, 757 (1998).

321 Quintal, supra note 320, at 747. Quintal also notes that trials in absentia are common in civil law countries. Id. at 739-42.

322 Centennial Universal Congress of Lawyers Conference, The Influence of International Law and International Tribunals on Harmonized or Hybrid Systems of Criminal Procedure, 4 Wash. U. Global Stud. L. Rev. 651, 655 (2005).

${ }^{323}$ Quintal, supra note 320, at 752. Rule 61 proceedings do not even afford defendants the rights normally accorded to defendants by civil law jurisdictions for in absentia trials. See Faiza Patel King, Public Disclosure in Rule 61 Hearings Before the International Criminal Tribunal for the Former Yugoslavia, 29 N.Y.U. J. INT'L L. \& POL. 523, 541 (1997) (“The design of the Tribunal's Rule 61 procedure prevents the accused from asserting many of the specific rights that have been recognized as applicable during in absentia trials.").

324 Quintal, supra note 320, at 752-53.

325 ICTY RPE, supra note 94, R. 61(C).

326 Quintal, supra note 320, at 753.

327 Id. At least one scholar believes that, at the very least, the standard applied at Rule 61 hearings should be "clear and convincing." See Winston P. Nagan, Strengthening Humanitarian Law: Sovereignty, International Criminal Law, and the Ad Hoc Tribunal for the Former Yugoslavia, 6 DuKE J. COMP. \& INT'L L. 127, 160 (1995). He reckons that having a higher standard would increase the legitimacy and credibility of the Tribunal. Id.

328 ICC RPE, supra note 155, R. 61(2). 
to secure his appearance. ${ }^{329}$ As with the ICTY RPE, this confirmation hearing in absentia was a concession to those delegations at the Rome conference that had unsuccessfully argued in favor of trials in absentia. ${ }^{330}$ One commentator has observed: "These confirmation hearings bear a certain resemblance to the Rule 61 proceedings before the ICTY."331 As such, from a due process perspective, they are equally deficient.

\section{Trial by Transcript}

As revealed by the Nuremberg experience, the civil law inquisitorial system has no qualms about admitting the testimony of witnesses through sworn affidavits, transcripts or other written means, as opposed to live in-court testimony. ${ }^{332}$ In its current form, international criminal procedure is influenced by the same policy. In fact, "the precedent available . . . from the ICTY allows for testimony via affidavit in what is at best a very weak cross-examination guarantee for the accused." 333

In particular, ICTY RPE Rule 92 bis (adopted in 2000) ${ }^{334}$ is designed to provide a mechanism for submitting evidence in writing that concerns matters more peripheral to the crimes charged, such as the background of the conflict, statistical analysis, the character of the accused and sentencing matters. ${ }^{335}$ In the first case to address the application of Rule 92 bis, the Trial Chamber noted that the rule's intent, consistent with civil law objectives, was "to try and cut down the length of these trials . . . [A] large amount of time in this Tribunal has been taken up with pointless and repetitive crossexamination, and this Rule is aimed at dealing with it." Thus, the rule "clearly evinces the trend towards broader resort to the admission of written evidence."336 Professor Zappalà has noted the deleterious effects this trend may have on due process:

Affidavits are in principle less trustworthy than depositions because they are taken ex parte, without any chance of cross-examination. Moreover, they present the same drawbacks as hearsay evidence, since they are out-of-court

\footnotetext{
329 Id.

330 See Kress, supra, note 182, at 610-11.

331 Id. at 611 .

332 See Patricia M. Wald, Dealing with Witnesses in War Crime Trials: Lessons from the Yugoslav
} Tribunal, 5 YALE HuM. RTS. DEV. L.J. 217 (2002) ("In civil law systems, however, there is a far wider use of written witness statements ...").

333 Walker, supra note 240, at 283.

334 See Megan A. Fairlie, Due Process Erosion: The Diminution of Live Testimony at the ICTY, 34 CAL. W. INT'L L. J. 47, 71 (2003). Although initially stating a preference for "live testimony" in its RPE, the ICTY has moved to a "no preference alternative." Id. Rule 92 bis essentially replaced Rule 94 ter, which had been even more permissive with respect to admission of written statements. Id. See Prosecutor v. Kordic, Case No. IT-95-14/2-Y (Sept. 18, 2000) (Appeals Chamber decision overruling Trial Chamber's admission of statement of deceased witness implicating accused that was not given under oath, never subject to cross-examination, uncorroborated by other evidence, and was verbally translated by an interpreter from Croatian to English before it was written down in English by an investigator whose native language was Dutch). See also Defrancia, supra note 4, at 1427-28.

335 ICTY RPE, supra note 94, R. 61(C). Moreover, Sub-rule 89(C) provides that "a Chamber may admit any relevant evidence which it deems to have probative value." Id., Sub-R. 89(C).

336 Zappalà, supra note 3 , at 138 . 
statements presented at trial ... When affidavits are submitted, defendants are clearly not confronted with the source of the evidence. Additionally, affidavits lack those elements of orality and direct examination that should characterize the presentation of evidence in adversarial trials. $^{337}$

The due process mischief sanctioned by ICTY Rule 92 bis was on display in Prosecutor v. Sikirica, ${ }^{338}$ where the Trial Chamber admitted into evidence, inter alia, two witness statements relating to arguably central issues in the Prosecutor's case. ${ }^{339}$ The Trial Chamber acknowledged that one of these statements was capable of "[constituting] a means of proof of an element of the genocide charge against the accused . .."340 And it characterized the other as "capable of going towards the proof of the crime of genocide with which Mr. Sikirica is charged." ${ }^{341}$ As a result, the defense sought to cross-examine these witnesses with respect to the full scope of their previous testimony. ${ }^{342}$ However, the Trial Chamber permitted only limited cross-examination. With respect to one of the statements, the Chamber held:

The fact that a witness's account is alleged to be one-sided is a matter which can be dealt with by comments in final submissions or the calling of evidence. The way to deal with new evidence alleged, to contradict the witness's evidence, is to call the new evidence. ${ }^{343}$

Thus, rather than permit the defense to challenge the witness directly and test his credibility viva voce with respect to bias and "new evidence," the Trial Chamber allowed Rule 92 bis to infringe on the defendant's confrontation rights.

In the case of Prosecutor v. Galic, the Trial Chamber allowed into evidence, pursuant to Rule 92 bis (C), the statements of two witnesses, since deceased. ${ }^{344}$ In granting an interlocutory appeal with respect to one of the statements, the Appeals

\footnotetext{
337 Id. at 137.

338 Prosecutor v. Sikirica, Case No. IT-95-8, Trial Chamber Decision on Prosecutor's Application to Admit Transcripts under Rule 92 bis (May 23, 2001).

339 The statements consisted of transcripts of testimony given in different trials. Although there had been the opportunity for cross-examination, this testimony involved different accused in separate proceedings.

340 Id. $\ 11$.

341 Id. 121 . The Trial Chamber admitted four other transcripts pursuant to Rule 92 bis. It acknowledged that one related to the accused in a "significant and direct way." Id., ๆ 35. The Trial Chamber did permit full cross-examination in relation to this statement. Id.

${ }^{342}$ Two other defendants were on trial with Sikirica: Dragan Kolundzija and Damir Dosen. The attorneys for all three of the accused wanted full cross-examination of these witnesses. Sikirica was permitted cross-examination "on the limited issue" of rapes committed at a detention camp (id. ๆ 21) and facts relating to intent (id. $\mid 11$ ).

343 Id. $₫ 21$.

344 Prosecutor v. Galic, Case No. IT-98-29-AR73.2, Decision on Interlocutory Appeal Concerning Rule 92 bis (C) (June 7, 2002).
} 
Chamber observed that parties may use Rule 92 bis statements to establish the acts and conduct of others (i.e., not the accused). ${ }^{345}$ Parties may then marshal such evidence to establish the state of mind of the accused. ${ }^{346}$ The Appeals Chamber provided the following example of the latter: "An easy example would be proof, in relation to Article 5 of the Tribunal's Statute, of the knowledge by the accused that his acts fitted into a pattern of widespread or systematic attacks directed against a civilian population. $" 347$ According to one commentator:

That these interpretations of the Rule are a far cry from its 'original purpose' is evident. It is further worth noting, however, that the admission of such statements without cross-examination, as the decision suggests, and as the Rule allows, runs contrary even to the precedent established at Nuremberg. [A cause for concern] is the nearly limitless discretion conferred upon the Trial Chambers in the employment of the Rule. Inherent in this enhanced discretion is the fact that determinations made by a Trial Chamber would likely only be reversed if the decision at issue evidences a clear abuse of discretion, a fact that conceivably may not bode well vis-à-vis the fair trial rights of the accused. ${ }^{348}$

ICC criminal procedure may be subject to the same vice. Rome Statute Article 69(2) permits previously recorded testimony, documents and transcripts (subject to the RPE) as evidence at trial. ${ }^{349}$ With respect to recorded testimony, Rule 68(a) of the ICC RPE requires that the Prosecutor and the defense have the opportunity to examine the witness during the recording. ${ }^{350}$ Nevertheless, "it will be for the judges to develop more specific criteria to give proper weight to the general principle, laid down in Article 69(2), that witnesses shall testify before the Court in person."351

\section{Double Jeopardy}

The integration of common and civil law circumscribes yet another fundamental right of international criminal defendants: the protection against double jeopardy. The Double Jeopardy Clause of the Fifth Amendment to the United States Constitution

\footnotetext{
345 Id. $\ 11$

346 Id.

347 Id. See also Daryl A. Mundis, Current Developments at the Ad Hoc Criminal Tribunals, 1 J. INT'L CRIM. JUST. 197, 218 (2003).

348 Fairlie, supra note 334, at 78-79.

349 Rome Statute, supra note 154, art. 69(2). See Kress, supra note 182, at 611. Still, Article 69(2) mandates that such admission not be prejudicial to or inconsistent with the rights of the accused. Rome Statute, supra note 154, art. 69(2).

350 ICC RPE, supra note 155, R. 68(a).

351 Kress, supra note 182, at 611.
} 
protects persons from being put twice in jeopardy for the same offense. ${ }^{352}$ While, as noted earlier, defendants in both the ad hoc Tribunals and the ICC have a right not to be placed in double jeopardy, ${ }^{353}$ that right is couched in the civil law protection of "non bis in idem" which roughly translates from Latin into: "Not twice for the same thing.,"354 Although double jeopardy and "non bis in idem" are roughly comparable, ${ }^{355}$ there is one significant due process difference, as explained by Professor Sean Murphy:

The principle of non bis in idem is similar to, but different from, the prohibition on "double jeopardy" in common law countries. Non bis in idem addresses the possibility of repeated prosecutions for the same conduct in different legal systems, whereas double jeopardy generally refers to repeated prosecutions for the same conduct in the same legal system. ${ }^{356}$

As a result, in contrast with the common law practice, non bis in idem permits the prosecutor to appeal an acquittal for errors of law and questions of fact. ${ }^{357}$ In France's civil law system, for example, the parties in a criminal case may appeal a conviction, an acquittal, a dismissal or a sentence. ${ }^{358}$ Moreover, on appeal a reviewing court may reverse and remand the case, or revise the judgment. ${ }^{359}$ Both prosecutorial challenge and appellate review of acquittals are anathema to common law notions of the double jeopardy protection. ${ }^{360}$

${ }^{352}$ U.S. Const. amend. V ("no person shall be ... subject for the same offense to be twice put in jeopardy of life or limb."). The clause provides three separate protections for criminal defendants: (1) protection against successive prosecutions for the same offense after acquittal (autre fois acquit); (2) protection against successive prosecutions for the same offense after conviction (autre fois convict); and (3) protection against multiple punishments for the same offense. See Monge v. California, 524 U.S. 721, 727-28 (1998).

353 See ICTY Statute, supra note 94, art. 10; ICTR Statute, supra note 96, art. 10; Rome Statute, supra note 154, art. 20. See also Jennifer E. Costa, Double Jeopardy and Non Bis In Idem: Principles of Fairness, 4 U.C. DAVIS J. INT'L L. \& POL'Y 181, 183 (1998) (“The double jeopardy/non bis in idem provisions of the Draft [ICC] Statute, however, draw primarily from the civil law tradition.")

354 See Keith R. Fisher, In Rem Alternatives to Extradition for Money Laundering, 25 LOY. L.A. INT'L \& COMP. L. REV. 409, 434-35 n. 116 (2003); Christensen, supra note 13, at 420.

355 See Fisher, supra note 354, at 434-35.

356 Murphy, supra note 300, at 79 n. 43. There is another important difference. Double jeopardy only applies within a sovereign. Thus, double jeopardy prevents a sovereign from prosecuting the same person for a single offense more than once. Meanwhile, non bis in idem is more flexible as to subsequent prosecutions by the same sovereign but bars prosecutions for a single offense by separate sovereigns. See . Costa, supra note 353, at 183 (1998).

357 Dax Eric Lopez, Not Twice for the Same: How the Dual Sovereignty Doctrine Is Used to Circumvent Non Bis in Idem, 33 VAND. J. TRANSNAT'L L. 1263, 1283 (2000) ('Unlike Common Law countries, however, prosecutors may appeal errors of law and questions of fact under non bis in idem.").

358 Costa, supra note 353, at 190.

359 Id.

360 See Zappalà, supra note 3, at 175 ("Generally speaking, it may be argued that in common law systems prosecutorial appeals would be seen as a violation of the protection against double jeopardy. On the other hand, in civil law countries the power of the Prosecutor to appeal against acquittal is a normal feature of the legal system."). In the United States, the U.S. Supreme Court has held that "it is one of the elemental principles of our criminal law that the Government cannot secure a new trial by means of an appeal even though an acquittal may appear to be erroneous." Green v. United States, 355 U.S. 184, 188 
The due process implications of this procedural wedge between common and civil law are on display in Prosecutor v. Rutaganda. ${ }^{361}$ In that case, the ICTR Trial Chamber acquitted Georges Rutaganda, a prominent Hutu businessman and former second vice president (youth wing) of a Hutu extremist militia (the "Interahamwe"), of war crimes (violation of common Article 3 of the Geneva Conventions and Additional Protocol II thereto) for his alleged role in directing attacks against Tutsis at the École Technique Officiel (ETO School) and the Nyanza gravel pit in the Kigali area. ${ }^{362}$ The Trial Chamber held that the prosecution failed to establish the required nexus between Rutaganda's criminal acts and the armed conflict. ${ }^{363}$ The prosecution challenged this factual finding on appeal and the Appeals Chamber reversed. ${ }^{364}$

Because the Trial Chamber had made factual findings recognizing a link between the ETO school and Nyanza massacres and the armed conflict, and had determined that Rutaganda had participated in these attacks, the Appeals Chamber concluded that no reasonable trier of fact could have failed to find beyond a reasonable doubt that there existed a nexus between Rutaganda's participation in the killings at the ETO School and the armed conflict. ${ }^{365}$ Since the Trial Chamber's erroneous conclusion that a nexus had not been established was the only basis for its acquittal of Rutaganda on the two counts of war crimes, the Appeals Chamber convicted him on those counts. ${ }^{366}$

To common law ears, the strange cluster of the words "the Appeals Chamber convicted him" sounds blasphemous. It signifies that the prosecution received a second bite at the apple. ${ }^{367}$ From a fairness perspective, a prosecutor's right to appeal acquittals is "not necessarily appropriate in international criminal proceedings." due process casualty that results from forcing the square peg of the common law system into the round hole of the civil law system.

C. Gravity

International criminal law deals with the most horrific, large-scale crimes human

(1957). The Court went on to articulate the policy behind the double jeopardy ban: "(T)hat the State with all its resources and power should not be allowed to make repeated attempts to convict an individual for an alleged offense, thereby subjecting him to embarrassment, expense and ordeal and compelling him to live in a continuing state of anxiety and insecurity, as well as enhancing the possibility that even though innocent he may be found guilty." Id. at 187-188. However, it should be noted that, even in common law systems, the prosecutor has a limited power to appeal based on errors of law. See Zappalà, supra note 3, at 175.

361 Prosecutor v. Rutaganda, Case No. ICTR-96-3, Judgment and Sentence (Dec. 6, 1999).

362 Nevertheless, for these acts he was convicted of genocide and crimes against humanity and sentenced to life imprisonment. Id.

363 Id. $\uparrow \uparrow 443-45$.

364 Prosecutor v. Rutaganda, Case No. ICTR-96-3-A, Appeal Chamber Judgment (May 26, 2003).

365 Id. 9580.

366 Id. 9584.

367 Zappalà, supra note 3, at 177.

368 Id. 
beings can commit. The horror of these crimes, as well as the intense suffering they visit on victims, have to some degree put the human rights movement on the horns of a dilemma: vindicate the due process rights of the accused or adequately punish the perpetrator? Professor Paul Dubinsky sees a normative priority evolution from the former to the latter: "A new subfield - call it "atrocity law" - [has] exerted increasing influence on the human rights movement as a whole, creating a shift in emphasis from procedural due process to holding perpetrators accountable and providing remedies to victims."369 As demonstrated above, the magnitude of the horror adjudged at Nuremberg likely played a part in limiting the due process protections afforded to defendants in that proceeding. ${ }^{370}$

The same consideration exerts a limiting force with respect to certain procedural protections offered to international criminal defendants today. This portion of the Article will focus on three areas where this has been an issue: (1) pre-trial detention and provisional release; (2) witnesses protection and victims' rights; and (3) the right to trial by jury.

\section{Pre-Trial Detention}

The general practice in the ad hoc Tribunals reveals that once the indictment is confirmed, the defendants are normally held in pre-trial detention. ${ }^{371}$ Pursuant to consistent Tribunal practice, the judge confirming the indictment also issues one or more arrest warrants addressed to relevant State authorities requesting the arrest and transfer of the accused. ${ }^{372}$ The indicted person should then be arrested and transferred to the custody of the Tribunal. ${ }^{373}$ Thereafter, the accused is detained at the UN Detention facility (either in the Hague or Arusha) and may be released only under the conditions set out in Rule 65 of the RPEs for both Tribunals. ${ }^{374}$

At this stage, an essential pre-trial prerogative for criminal defendants "is the right to apply for provisional or interim release." ${ }^{, 75}$ In fact, a policy for provisional release is a "natural outgrowth of the presumption of innocence." 376 For to presume that an accused is innocent means, among other things, that punishment cannot begin until an accused is convicted. ${ }^{377}$ As a result:

${ }^{369}$ Paul R. Dubinsky, Human Rights Law Meets Private Law Harmonization: The Coming Conflict, 30 YALE J. INT'L L. 211, 213 (2005). See also Katz Cogan, supra note 243, at 112 (explaining that the relative lack of interest in the rights of international criminal defendants can be explained, in part "by the reversal, in the international context, of the typical left/right domestic political alignment on prosecutorial prerogatives.").

${ }_{370}^{371}$ See Zappalà, supra note 3, at 21-22.

371 See id. at 70 .

${ }_{372}^{373}$ See id.

${ }^{373}$ See id.

374 See id.

${ }^{375}$ Knoops, supra note 14, at 109.

${ }^{376}$ Daniel J. Rearick, Innocent Until Alleged Guilty: Provisional Release at the ICTR, 44 HARV. INT'L L. J. 577 (2003).

377 See id. 
[D]etention must serve some other distinguishable goal. Unless the prosecution can show strong countervailing interests such as danger to victims or witnesses or a risk of flight, the accused must be temporarily released pending trial. The argument for temporary release is at its strongest when the accused faces a long period of detention before the court decides his guilt or innocence. ${ }^{378}$

Nevertheless, in contravention of the presumption of innocence, Rule 65 of the ad hoc Tribunals' RPEs (governing pre-trial release) was for many years extremely restrictive and placed on the accused the burden of showing "exceptional circumstances" to justify release. ${ }^{379}$ Under this rule, provisional release was granted "only in very rare cases in which the condition of the accused, notably the accused's state of health, is not compatible with any form of detention. ${ }^{380}$

Although Rule 65 of each RPE has been amended to remove the "exceptional circumstances" requirement, ${ }^{381}$ the burden is still on the accused to prove that he will appear for trial and not pose a danger to any victim, witness, or other person. ${ }^{382}$ Moreover, both the Statutes and RPEs of the Tribunals "lack clear and precise criteria with regard to the application of the concrete possibility of release on bail." ${ }^{383}$ As a

378 Id.

379 See Knoops, supra note 14, at 109. See also Zappalà, supra note 3, at 70 ("Originally, Rule 65 was extremely restrictive and provided for provisional release only in exceptional circumstances, which the accused had to prove."); ICTY RPE, supra note 94, former R. 65(B); ICTR RPE, supra note 99, former R. 65(B).

380 Prosecutor v. Blaskic, Case No. IT-95-14-AR, Decision Rejecting a Request for Provisional Release (Mar. 3, 2000).

381 See Knoops, supra note 14, at 109.

382 See, e.g., ICTY RPE, supra note 94, R. 65 (A) \& (B). See also Matthew M. DeFrank, Provisional Release: Current Practice, a Dissenting Voice, and the Case for a Rule Change, 80 TEX. L. REV. 1429, 1449 (2002); Knoops, supra note 14, at 112. This runs afoul of prevailing international norms. For example, Article 9(3) of the International Covenant on Civil and Political Rights states:

Anyone arrested or detained on a criminal charge shall be brought promptly before a judge ... and shall be entitled to trial within a reasonable time or to release. It shall not be the general rule that persons awaiting trial shall be detained in custody, but release may be subject to guarantees to appear for trial, at any other stage of the judicial proceedings, and, should occasion arise, for execution of the judgment (emphasis added). ICCPR, supra note 57.

Article 6(2) of the European Convention on Human Rights declares that "[e]veryone charged with a criminal offense shall be presumed innocent until proven guilty according to law." ECHR, supra note 60 . Article 6(1) includes the right to a fair and public hearing within a reasonable time. Id. Together these rights are usually taken to require that "the prosecution must overcome the presumption of innocence by demonstrating that the accused is likely to flee or commit a new crime before it may detain him prior to conviction." See Patricia Wald \& Jenny Martinez, Provisional Release at the ICTY: A Work in Progress, in ESSAYS ON ICTY PROCEDURE AND EVIDENCE 231, 233-34 (Richard May et al. eds., 2001).

383 Knoops, supra note 14, at 109. 
result, "it still remains true that liberty is the exception while detention is the rule" "384 and, for the most part, "post-amendment, provisional-release practices operate in exactly the same manner." 385

Nor can one be sanguine about the prospect of a more progressive provisional release regime for the ICC. The Rome Statute allows the accused to apply for provisional release in two situations: (1) to the competent authorities in the custodial State pending surrender proceedings, while being detained in that State (pursuant to Article 59(3)) ${ }^{386}$; and (2) to the ICC once the accused is detained in the Hague pending trial (pursuant to Articles $60(1),(2)) .{ }^{387}$ In the case of the custodial State, authorities may only allow provisional release when justified by "urgent and exceptional circumstances" and in the presence of sufficient safeguards to ensure its ICC surrender obligations. ${ }^{388}$ Once in ICC custody, the Pre-Trial Chamber may grant provisional release only if it is not satisfied that the following conditions are met: (1) no reasonable grounds exist for believing that the accused has committed the particular crime; or (2) his arrest appears no longer necessary (i.e., to ensure appearance at trial or to prevent obstruction of the investigation and trial). ${ }^{389}$

Unfortunately, similar to the ad hoc Tribunals and contrary to Article 9(3) of the ICCPR, both forms of ICC provisional release are framed on the presumption in favor of detention. ${ }^{390}$ This means that "both the ad hoc tribunals and the ICC endorse a provisional release standard that deviates from human rights law."391 According to one commentator: "The only justification for this stringency that comes to mind is the gravity of the offenses over which the Tribunal has jurisdiction and the desire to avoid a public outcry over allowing accused persons to be at large." 392

\section{Witness Protection and Victim Rights}

There is an ineluctable tension in certain phases of war crimes prosecutions between upholding the due process rights of the accused and assuring the safety and dignity of witnesses to unspeakable horrors. Not surprisingly, that tension often resolves itself in favor of the victims/witnesses. At the same time, in the eyes of many, the awesome gravity of the crime transforms the juridical status of the victim from mere bystander to party opponent. Investing the victim with such procedural stature and access

\footnotetext{
384 Zappalà, supra note 3 , at 70.

385 DeFrank, supra note 382, at 449. Although some ICTY defendants have been granted pre-trial provisional release, no ICTR defendants have. See Rearick, supra note 376, at 590 (noting that 12 ICTY applications for provisional release were granted between 2000 and 2003).

386 Rome Statute, supra note 154, art. 59(3).

387 Id. art. 60(1), (2).

388 Id. art. 59. See Knoops, supra note 14, at 112.

389 Rome Statute, supra note 154, art. 58(1). See Knoops, supra note 14, at 112.

390 Knoops, supra note 14, at 112. See also William A. Schabas, AN InTRODUCTION To ThE ICC109

391 Knoops, supra note 14, at 112.

392 Nsereko, supra note 122, at 532 (emphasis added).
} (2001) 
may improperly tilt the scales of justice overwhelmingly in favor of the prosecution. This section will explore how that could happen.

\section{a. Witness Anonymity and Due Process}

The proceedings in a witness protection motion in the case of Prosecutor $v$. Tadic $^{393}$ read somewhat like a legal morality play pitting the value of safeguarding a defendant's rights against the necessity to shield vulnerable witnesses. Dusko Tadic, an ethnic Serb from Bosnia-Herzegovina, was arrested in Germany in early 1994 and charged by German authorities with crimes committed in the Omarska prison camp during the spring of 1992. Pursuant to a request by the ICTY, Germany transferred custody of Tadic to the ICTY in April 1995. ${ }^{394}$

The ICTY indicted Tadic on 132 counts of crimes against humanity and war crimes. ${ }^{395}$ These crimes included "forcible sexual intercourse or rape, willful killing or murder, willfully causing grave suffering or serious injury, torture, cruel treatment and the commission of inhumane acts ...,396

As the prosecution prepared its case against Tadic, it realized that several traumatized witnesses were unwilling to testify in open court. ${ }^{397}$ As a result, on May 18, 1995, the prosecution filed its Motion Requesting Protective Measures for Victims and Witnesses. ${ }^{398}$ Out of fourteen prayers for relief, two requested complete witness anonymity. ${ }^{399}$ Of those, one requested "that testimony of . . witnesses may be given using voice and image altering devices or by not transmitting the image of the accused to the defense." $" 400$ The other requested that, inter alia, the "prosecution may withhold from the defense and the accused the names of, and other identifying data concerning witnesses G, H, I, J, and K."

In a controversial 2-1 decision, the Trial Chamber granted the motion. It began by acknowledging that witness anonymity is an extraordinary measure in traditional domestic criminal trials and that it could be a barrier to accurate fact-finding. ${ }^{402}$ In addition, Article 21 of the ICTY Statute gave Tadic the right "to examine, or have

\footnotetext{
393 Prosecutor v. Tadic, Case No. IT-94-1,Trial Judgment (May 7, 1997) [hereinafter Tadic Trial Judgment].

394 See id.

395 Prosecutor v. Tadic, Case No. IT-94-1, Indictment (Feb. 13, 1995).

396 Id.

397 See Alan Tieger, Address at War Crimes Tribunals: The Record and the Prospects Conference at the Washington College of Law (Mar. 31-Apr. 1, 1998), in the Prosecutor v. Dusko Tadic, 13 AM. U. INT’L L. REV. 1441, 1446-47 (1998) (ICTY Senior Trial Attorney stated that "there were certainly witnesses who were too traumatized or too embittered to testify.").

398 Prosecutor v. Tadic, Case No. IT-94-1-T Protective Measures Decision (Aug. 10, 1995)[hereinafter Tadic Protective Measures Decision].

399 Id. $\mid 3$.

400 Id.

401 Id.

402 Id. at 9 54, 60, 67.
} 
examined, the witnesses against him" and to receive "a fair and public hearing." 403 The Trial Chamber pointed out, however, that Article 21 is expressly subject to Article $22,{ }^{404}$ which provides for witness protection including "the conduct of in camera proceedings and the protection of the victim's identity." 405

The Trial Chamber then acknowledged that courts interpreting international instruments phrased similarly to Article 21 have uniformly rejected witness anonymity protective measures in criminal cases. ${ }^{406}$ Nevertheless, the Trial Chamber distinguished those cases on both factual and legal grounds. Factually, it noted that, in contrast to the cases cited, the Tribunal had a particular dependence on eyewitness testimony ${ }^{407}$ in a climate of "terror and anguish among the civilian population." Chamber distinguished the cases on the basis of the Statute's "unique legal framework," which provides specially for the protection of victims and witnesses. ${ }^{409}$ Then, most importantly for the analysis here, the Chamber found that standards applicable to "ordinary criminal and ... civil adjudications" were not appropriate for the "horrific" crimes and then-ongoing conflict in the former Yugoslavia. ${ }^{410}$

Thus, the extraordinary nature of the crimes at issue was a factor in adopting measures that circumscribed Tadic's right to a fair trial. Judge Ninian Stephen of Australia dissented, however, writing that complete witness anonymity simply went too far. ${ }^{411} \mathrm{He}$ indicated that anonymity offended notions of due process by depriving the defense of its ability to demonstrate that a witness's testimony could be prejudiced, hostile or unreliable. ${ }^{412}$ And he deplored the potential conviction of a man on such serious charges through the use of evidence appearing as nothing more than a "disembodied and distorted voice transmitted by electronic means." "113 Given the stakes, he concluded, the use of unqualified immunity is not authorized by the Statute insofar as it does not comport with the Article 21(4) "minimum guarantee" of the rights of the accused. $^{414}$

403 ICTY Statute, supra note 94, art. 21.

404 Id. art. 22.

405 Tadic Protective Measures Decision, supra note 398, ๆ 26.

406 See, e.g., Kostovski Case, 166 Eur. Ct. H.R. (ser. A) at 21 (1989) ("The right to a fair administration of justice holds so prominent a place in a democratic society that it cannot be sacrificed to expediency ... [The] use of anonymous statements as sufficient evidence to found a conviction [is] irreconcilable with the guarantees contained in Article 6 [of the European Convention for the Protection of Human Rights and Fundamental Freedoms]." (citations omitted).

407 Statistics support the crucial nature of witness testimony at ICTY trials. For example, from January 1, 1998 through July 1, 2001, 971 victim-witnesses traveled to testify at ICTY trials in the Hague. Furthermore, the use of witnesses increased as work intensified: from July 31, 200 to July 31, 2001, the ICTY Victims and Witnesses Section handled 550 witnesses from thirty different countries. All of these witnesses testified in only eight trials conducted that year. See Wald, supra note 332, at 219.

408 Tadic Protective Measures Decision, supra note 398, ๆ 23.

409 Id 127.

410 Id. 928.

411 Id. (Stephen, J., dissenting in part).

412 Id. 947.

413 Id. ๆ 31.

414 Id. ๆ 30. 
Since Tadic, the ICTY has not granted the extreme remedy of complete witness anonymity. ${ }^{415}$ Nevertheless, one cannot say that the remedy is a "dead letter" ${ }^{416}$ and the specter of anonymity measures hangs over every war crimes prosecution, "given the unusual dangers" faced by witnesses and the "limited ability" to protect them. ${ }^{417}$ As a result, "the potential for allowing anonymity from the accused ... represents a potential danger in future adjudication.,, 418

\section{b. Victims' Rights}

The future of international criminal justice is poised to alter the juridical status of atrocity victims. The ICC's Rome Statute gives victims of humanity's most serious crimes a much more significant role than has any previous international criminal institution. ${ }^{419}$ In fact, unlike the ad hoc Tribunals, victims actually have standing in their own right at the ICC. According to the Rome Statute, the ICC must "permit their [victims'] views and concerns to be presented and considered at stages of the proceedings determined to be appropriate by the Court." ${ }^{\text {"420 }}$ Victims have a right to be heard, as well as to speak: the prosecutor and judges must consider victims' interests in making a range of decisions, including whether to initiate an investigation into particular allegations ${ }^{421}$ and whether to bring charges. ${ }^{422}$

In a recently published decision, the ICC held in its case regarding the Situation in the Democratic Republic of Congo (DRC) that victims may participate at the earliest stages of an investigation. In Decision on the Applications for Participation in the Proceedings of VPRS 1, VPRS 2, VPRS 3, VPRS 4, VPRS 5 and VPRS $6,{ }^{423}$ the victims, who allegedly suffered human rights abuses at the hands of various uncharged

415 See Wald, supra note 332, at 223; Defrancia, supra note 4, at 1410 ("[L]ater jurisprudence seems to be lessening the chance that there will be another case in which witness identity is completely withheld from the accused. ..").

416 Defrancia, supra note 4, at 1410.

417 See Developments in the Law, International Criminal Law, Fair Trials and the Role of International Criminal Defense, 114 HARV. L. REV. 1982, 1990 (2001) [hereinafter Fair Trials Article].

418 Defrancia, supra note 4, at 1438. Indeed, it has been observed that "the Statute does not take a definite position on the admissibility of anonymous testimony whereby a person's identity is kept secret. This topic has been a controversial issue for a long time. It seems that the question is left to a case-by-case balancing between security needs and protection of the defendant's rights, with the final determination made by the judge." Caianiello \& Illuminati, supra note 5, at 448 .

419 See Theo van Boven, The Position of the Victim in the Statute of the International Criminal Court, in REFLECTIONS ON THE INTERNATIONAL CRIMINAL COURT: EsSAYS IN HONOUR OF AdRIAAN Bos 77, 77 (Herman A. M. von Hebel et al. eds., 1999). Cf. id. at 81 (noting that "the ICTY Statute and Rules place victims largely in an auxiliary role."). See generally Sam Garkawe, The Victim-Related Provisions of the Statute of the International Criminal Court: A Victimological Analysis, 8 InT'L REV. ViCTOMOLOGY 269 (2001).

${ }^{420}$ Rome Statute, supra note 154, art. 68(3). Article 68(3) goes on to state that this must be consistent with defendants' rights. Id.

421 Id. art. 53(1)(c).

422 Id. art. 53(2)(c).

423 Decision on the Applications for Participation in the Proceedings of VPRS 1, VPRS 2, VPRS 3, VPRS 4, VPRS 5 and VPRS 6, Situation in the Democratic Republic of Congo (ICC-01/04), Pre-Trial Chamber I, 17 January 2006. 
perpetrators in the DRC, argued that pursuant to Article 68(3) of the Rome Statute they should be permitted to present to the Chamber their "views and concerns" regarding the investigation. ${ }^{424}$ The Prosecutor opposed the application on, inter alia, the following grounds: (1) at that stage there were no "proceedings" within the meaning of article 68(3) of the Statute because the word "proceedings" does not encompass the investigation of a "situation"; and (2) the participation of the victims at such a preliminary stage would be "inappropriate." ${ }^{425}$ The Pre-Trial Chamber rejected this argument:

The interpretation of article 68(3) as being applicable to the investigation stage is ... consistent with the object and purpose of the victims participation regime established by the drafters of the Statue, which ensued from a debate that took place in the context of the growing emphasis placed on the role of victims by the international body of human rights law and by international humanitarian law. . . In the Chamber's opinion, the Statute grants victims an independent voice and role in proceedings before the Court. It should be possible to exercise this independence, in particular, vis-à-vis the Prosecutor of the International Criminal Court so that victims can present their interests. As the European Court has affirmed on several occasions, victims participating in criminal proceedings cannot be regarded as "either the opponent - or for that matter necessarily the ally - of the prosecution, their roles and objectives being clearly different. ${ }^{426}$

In fact, this unique role carved out for victims will have an impact through the entire course of ICC proceedings. What is perhaps the Rome Statute's most innovative provision allows the court to reject a plea bargain or request the presentation of evidence against a defendant who has already pled guilty if "a more complete presentation of the facts of the case is required in the interests of justice, in particular the interests of the victims., 427

Such victim empowerment essentially reconfigures the structure of international criminal justice. ${ }^{428}$ Although in principle the enumerated victim rights must be exercised

\footnotetext{
${ }^{424} I d .923$.

${ }^{425} I d$. 925 . Although the Prosecutor did not provide specific reasons, presumably victim participation would be "inappropriate" at that stage, inter alia, given its effects on the due process rights of potential defendants. The Chamber had previously appointed an ad hoc defense counsel to represent potential interests of any future defendants. Curiously, although he objected to the participation of these particular victims and their counsel [Id. १ף 104, 105], ad hoc defense counsel did not object to the application of Article 68(3) at that stage of the proceedings. Id. $\mid 24$.

${ }^{426} I d$. 9 I斤 $50-51$.

${ }^{427}$ Id. art. 68(4).

${ }^{428}$ One can draw an analogy between the projected role of victims at the ICC to the contemplated role of victims in the American Victims' Rights Amendment ("VRA"). Critics of the VRA see it as infringing on criminal defendants' due process rights by adding to the system another structural component tilting against the defendant's interests. See James M. Dolliver, Victims' Rights Constitutional Amendment: A
} 
without prejudice to those of the accused, it is difficult to reconcile this with the extraordinary influence victims may exert over the process. ${ }^{429}$ They are suddenly endowed with juridical life and can function as juridical actors with a built-in axe to grind. ${ }^{430}$ The prospect of an ICC judge soliciting the views of a quasi-party to the litigation, who has been brutalized, disfigured, and dispossessed, could understandably send shudders down the collective spine of the international criminal defense bar.

Respect for the rights of defendants requires a neutral, dispassionate setting in which relatively neutral, dispassionate actors go about their business. Such critical decisions as initiating an investigation into particular allegations, bringing certain charges, or rejecting a plea bargain, traditionally the province of prosecutors and judges assumed to be examining the evidence without any untoward motive or bias, may now be affected by the moving cries of the fallen. And due process may suffer as a result. As one commentator points out:

Bad Idea Whose Time Should Not Come, 34 WAYNE L. REV. 87, 90 (1987) ("By constitutionally emphasizing the conflict between the victim and the accused and placing the victim in the role of a quasiprosecutor or co-counsel, the victims' rights amendment represents a dangerous return to the private blood feud mentality."); Robert P. Mosteller, Victims' Rights and the United States Constitution: An Effort to Recast the Battle in Criminal Litigation, 85 GEO. L. J. 1691, 1712 (1997) (stating that, through the proposed American Victims' Rights Amendment, analogous victim participation in the prosecution process would effect a "fundamental reconceptualization of criminal litigation" and would diminish defendants' rights); Vik Kanwar, Capital Punishment as "Closure": The Limits of a Victim-Centered Jurisprudence, 27 N.Y.U. REV. L. \& Soc. CHANGE 215, 227 (2001-2002) ("While at least twenty-nine states have amended their constitutions to protect victims' rights, efforts at amending the U.S. Constitution have met with considerably more caution and resistance. The main obstacle to the "rights" aspect of the movement is the concern that these would conflict with or trump defendants' rights).

429 See Dolliver, supra note 428, at 90.

${ }^{430}$ Once again, an analogy to the American Victims' Rights movement may be instructive. Certain theorists who have considered victims rights in the United States on a more abstract, structural level, dispense with identifying either the courts or the prosecutor as "the state" and view both as part of what Pierre Bourdieu calls the "juridical field." According to Bourdieu:

The juridical field is a social space organized around the conversion of direct conflict between directly concerned parties into juridically regulated debate between professionals acting by proxy. It is also the space in which such debate functions. These professionals have in common their knowledge and their acceptance of the rules of the legal game, that is, the written and unwritten laws of the field itself, even those required to achieve victory over the letter of the law .... [T] he jurist has most often been defined as a "third person mediator." In this definition, the essential idea is mediation, not decision.

Pierre Bordieu, The Force of Law: Toward a Sociology of the Juridical Field, 38 HASTINGS L.J. 805, 831 (1987). Kanwar posits that the juridical form of sovereignty (mediation) is already a weaker form than the political form (decision). It relies almost entirely on the acceptance of the proxy function of legal professionals and the renunciation of direct violence by the "directly concerned parties." Kanwar, supra note 428 , at 253. Kanwar concludes that the demand for increased accountability to victims "has put new constraints on courts, prosecutors, and parole boards, among other juridical actors, and it attacks the very raison d'être of the juridical field." Id. 
When the rights of victims and the accused seemingly conflict, we risk the abrogation of important due process rights as their distinction collapses into larger notions of justice and fairness ... While fairness rightly involves the simultaneous considerations of victims and accused in regard to allegations of war crimes and crimes against humanity, the Tribunals will be wise to isolate the important procedural protections for the rights of the accused and to prioritize those interests as paramount. ${ }^{431}$

Melding this "ICC victims' bill of rights" into critical procedural stages of its criminal litigation schema, the Rome Statute may adulterate, and ultimately dilute, basic structural due process protections of ICC defendants. According to Alison Marston Danner and Jenny S. Martinez, the "victim-oriented, civil law model of human rights" leads to inordinate [c] oncern for symbolic vindication of violations of victims' human rights" and "has proven a more potent influence than worries over potential violations of defendants' rights." ${ }^{432}$

\section{The Right to Jury Trials}

Genocide has been called the "crime of crimes." ${ }^{433}$ In terms of societal opprobrium, crimes against humanity and war crimes feature prominently at the top of the list as well. ${ }^{434}$ These crimes saddle international criminal justice with a tremendous burden "because of a perceived duty to convict large numbers of individuals culpable in widespread outbreaks of extraordinary evil." "435 Put differently, "the extreme character of the crimes alleged before international criminal courts makes the case for accountability stronger than in domestic prosecutions. ${ }^{436}$ From this premise, John Haberstroh concludes:

Ultimately, then, war crime trials and their standards are for 'the Hitlers, the Goerings, the Pol Pots, the Milosevics, the Karadzics, and other architects of genocide ...' Perhaps these trials should not be for 'ordinary murderers,' as their multitudes of purposes may take precedence over the dispensation of justice for matters of less-than-

431 Defrancia, supra note 4, at 1437.

432 Alison Marston Danner \& Jenny S. Martinez, Guilty Associations: Joint Criminal Enterprise, Command Responsibility, and the Development of International Criminal Law, 93 CAL. L. REV. 75, 146 (2005).

${ }^{433}$ See Allison Marston Danner, Constructing a Hierarchy of Crimes in International Criminal Law Sentencing, 87 VA. L. REV. 415, 491-92 (2001).

434 Id.

435 John Haberstroh, The Alien Tort Claims Act \& Doe v. Unocal: A Paquete Habana Approach to the Rescue, 32 DENV. J. INT'L L. \& POL'Y 231, 263 (2004). Haberstroh goes on to observe that "Genocide is the exemplar of such evil and the creation of the ad hoc tribunals is commonly understood as an attempt to put a stop to that atrocity." Id. at 263-64.

436 Katz Cogan, supra note 243, at 114. 
extraordinary evil. Perhaps this also helps to explain why their standards diverge from the practice in U.S. criminal courts ... ${ }^{437}$

Among the more conspicuous divergences is the lack of jury trials. ${ }^{438}$ That the architects of our international criminal justice institutions opted for bench trials to adjudicate liability is perhaps understandable in the mass atrocity context. Right or wrong, there has been an international perception that jurors are unqualified to sit as finders of fact given the complexities of modern international criminal law and the expertise required for forensic fact-finding. ${ }^{439}$ Moreover, there is a fear that jurors will be more likely to vote according to their personal biases and popular sentiment than as trained professionals. ${ }^{440}$

If jurors were impaneled for genocide and war crimes trials, these tendencies might very well lead to jury nullification (going either way - unjust conviction or acquittal) and the international community has found this prospect unacceptable. ${ }^{441}$ According to former U.S. Ambassador-At-Large for War Crimes Issues David Scheffer, one of those architects just mentioned:

But, when you really think about it, you probably do not want a jury of twelve peers from all parts of the world to sit in judgment of your defendant in this court for these types of crimes. You want very expert judges who know the law, and who can understand the complexities of atrocity law, ${ }^{44}$ to be the judges of your innocence or guilt for these particular crimes. $^{443}$

437 Haberstroh, supra note 435, at 265.

438 One commentator has gone so far as to say that the disutility of acquitting a genocidaire is a harm of an order of magnitude greater than that of freeing an ordinary murderer. See Fair Trials Article, supra note 417, at 1992. The commentator then asked: "If the presumption of innocence really reflects 'a rational world, should not the prosecutor's burden of persuasion drop considerably in cases involving charges of genocide?" Id.

439 See Amy Powell, supra note 225, at 2355 (2004).

440 Id.

441 Id. at 2357.

442 For an explanation of the term "atrocity law," see David J. Scheffer, The Future of Atrocity Law, 25 SUFFOLK TRANSNAT'L L. REV. 389, 393-402 (2002) (“The crimes include war crimes, genocide, terrorism, crimes against humanity, and within the latter term can be found crimes of torture or of slavery or of apartheid ... The international law that is or will be applied by each court varies in description: we speak of the law of war, laws and customs of war, the laws of armed conflict, military law, international humanitarian law, international criminal law, human rights law."). While "complexity" could be distinguished as a separate rationale for using professional judges, as opposed to lay jurors in these cases, it is intimately related to the "gravity" concept because the complexity of the crimes arises, in part, from their enormous scale. By the same token, the overwhelming scale of the mass murder involved is a key component of the gravity phenomenon.

${ }^{443}$ Scheffer, supra note 206, at 1572 (emphasis added). See also Mark A. Drumbl, Punishment, Postgenocide: From Guilt to Shame to Civis in Rwanda, 75 N.Y.U. L. REV. 1221, 1312 n.453 (2000) ("[There is an] assumption of international criminal law that justice requires an ethnically neutral tribunal consisting only of persons disconnected from the tragedies."); Bryan F. MacPherson, Building an International Criminal Court for the 21st Century, 13 CONN. J. INT'L L. 1, 25 (1998) ("No credible claim 
Still, as Ambassador Scheffer himself implicitly acknowledges, ${ }^{444}$ the absence of the jury feature stands out like a due process sore thumb to most common law attorneys. For them, it is the bulls-eye on the back of international criminal procedure and they lob their verbal grenades at it with glee. ${ }^{445}$

\section{The Relationship Among the Limiting Forces}

Although this Article has treated the phenomena of fragmentation, integration, and gravity as separate and discrete concepts, they are to some degree fluid and often overlap with one another. Moreover, consistent with this, the due process protections they limit can typically be analyzed through the prism of more than one of them at a time.

Take the right to jury trials, for example. The analysis above considered the absence of jury trials in international criminal courts as a function of the exceptional severity of the crime. While gravity may be a prominent limiting factor, it is certainly not the only one. Integration plays a part as well since, in civil law countries, most cases are decided primarily by judges. ${ }^{446}$ Juries are used only for trying very serious crimes such as treason, murder, or kidnapping. ${ }^{447}$ And even in those cases, lay people sit together with professional judges. ${ }^{448}$ In fact, these countries use the term "jury" to "describe what is, in reality, a mixed panel of professional judges and lay people, who deliberate together." 449

Similarly, fragmentation can be seen as a limiting factor with respect to the jury trial right. In particular, an international jury of the defendant's "peers" would create the appearance of justice imposed from the outside, consisting of "world citizens" with no understanding of the relevant community experience or ethos. ${ }^{450}$ Further, the exorbitant cost, logistical hurdles, and political complications of selecting jurors from all over the world and bringing them to the Hague means that using an international jury would be exceptionally difficult, if not practically impossible. ${ }^{451}$

of bias could be made against a court composed of distinguished judges from throughout the world community.").

${ }^{444}$ Scheffer, supra note 206, at 1572.

445 See, e.g., Walker, supra note 240 ("Another primary criticism of the ICC Statute is the fact that it conflicts with the Sixth Amendment right to a jury trial."); Powell, supra note 225, at 2343 ("One of the reasons for U.S. opposition to the ICC is the lack of a jury trial."); Casey, supra note 13, at 870 ("The fundamental difference between criminal procedure in the United States, and that adopted in the Rome Statute, including such elements as ... the lack of jury ... suggests that no American could receive a fair trial, as the term is understood and accepted in the United States, before the ICC.").

${ }^{446}$ See Scheffer, supra note 206, at 1572 ("Civil-law procedure involves only judges.").

447 See William T. Pizzi \& Mariangela Montagna, The Battle to Establish an Adversarial Trial System in Italy, 25 Mich. J. INT’L L. 429, 433 (2004).

${ }^{448} I d$. at 433-34. This is the system used in Italy, France, Germany and other continental countries. Id.

${ }^{449} I d$. at 434 n. 12.

${ }^{450}$ Powell, supra note 225, at 2367.

${ }^{451}$ See id. 
And so it goes with the other due process protections. Those rights affected by fragmentation - for example, protections against unreasonable searches and seizures, as well as arrest and detention - are equally impacted by the gravity phenomenon. Thus, as pointed out previously with respect to search and seizure, States may "ignore the privacy interests of suspects or accused persons . . . in the perceived greater interest of . . . eradicating impunity for heinous crimes . .."452 Similarly, "integration" may affect defense efforts to collect evidence. As noted in connection with the Nuremberg experience, civil law defense attorneys are accustomed to a magistrate spearheading investigative efforts and often do not grasp the importance of conducting their own investigations. $^{453}$

The rights constricted by "integration" are also impacted by gravity considerations. Use of documentary evidence at trial, as opposed to live testimony, can be perceived, at least in part, as protecting the interests of traumatized victim-witnesses unwilling to relive the terror of these depraved crimes in open court. With respect to double jeopardy, the fear of letting a genocidaire walk must certainly factor into the world community's decision to hedge its bets and provide for prosecutorial appeals. The same might be said for the quasi-trial in absentia provided for by the drafters of ICTY Rule 61 - better to expose the infamy of war criminals on the lam, they undoubtedly reckoned, than to keep their nefarious deeds hidden from public view. ${ }^{454}$ Fragmentation plays a role here as well - many of those war criminals evade capture with the help of States and the Rule 61 hearing helps portray them to the world as accessories after the fact.

Finally, the rights above that were described as impacted by "gravity" are also subject to the other restricting forces. The overwhelming preference for pretrial detention, for example, while certainly affected by the heinousness of the crimes committed, is also a function of fragmentation. Given a global setting, with geographically dispersed perpetrators, victims, crime scenes, police forces, prison facilities, and courthouses, the international criminal defendant clearly poses a greater flight risk than his homebound domestic counterpart.

By the same token, the rights accorded to victims in the ICC setting are not the mere product of "gravity." Victims of crimes in continental Europe have stronger rights to enforce, and take part in, criminal law proceedings than victims in the United States. ${ }^{455}$ In addition to the victim's right in the civil law tradition to attach her tort suit to a criminal prosecution, many civil law countries accord victims the right to prosecute certain types of crimes if the prosecutor fails to do so. ${ }^{456}$ Thus, the "integration" phenomenon is also responsible for broadening the victim's role at the expense of the defendant's due process rights.

452 Edwards, supra note 245, at 333.

453 See Alvarez, supra note 24, at 2037.

454 See L.C. Vorah, Symposium on "The ICTY 10 Years On: The View from Inside, The First Year, Some Insight into the Early Years, 1 INT’L CRIM. JUST. 388, 393-94 (2004).

455 See John C. Reitz, Political Economy as a Major Architectural Principle of Public Law, 75 TUL. L. REV. 1121, 1134 n.38 (2001).

456 Id. 


\section{CONCLUSION: TOWARD A TRULY INTERNATIONAL CRIMINAL PROCEDURE}

So we have reached a crossroads. The growth of international criminal procedure has seen attendant, even structurally intertwined, growth in the due process rights of defendants. But the fully developed national models, to which international due process seems to aspire, are fundamentally different. They do not have the unenviable task of harnessing the law enforcement cooperation and resources of free-agent sovereigns, fusing together the components of two often-mismatched legal systems, and bringing to justice the law's most depraved monsters. These are the challenges of international criminal institutions and, as this Article has demonstrated, they have, in some respects, helped retard the further development of due process. But is this irreversible?

The indications are that it is not. Rather than calcify, the process would appear to be fluid and dynamic. And the history of the human rights movement itself helps to explain why. As Professor Dubinsky suggested earlier, the human rights movement has evolved in its treatment of criminal matters. ${ }^{457}$ After being initially focused on atrocity prosecution issues (as evidenced by Nuremberg, the Genocide Convention, and the Geneva Conventions), it turned its attention to the process by which prosecution is achieved. It sought to ensure fairness for the individual swallowed up by the imposing machinery of criminal adjudication and pitted against the limitless resources of the State. ${ }^{458}$ And so followed the UDHR, the ICCPR and a host of other instruments, both international and regional, designed to safeguard civil, political and judicial rights.

But with the fall of the Iron Curtain and a new worldwide surge of irredentist and ethnic violence, the pendulum began to swing the other way. Atrocity prosecution was again at the fore but this time it reflected the due process advances made during that dormant period between Nuremberg and the establishment of the ad hoc Tribunals. By now, the latter have been in operation for over ten years and are slated to terminate operations by this decade's end. Although the ICC is just getting under way, the massive energy and resources devoted to atrocity prosecution in the 1990s has begun to peter out. $^{459}$ A new phrase, "tribunal fatigue," has been coined ${ }^{460}$ and it certainly seems as if the pendulum could be swinging back again toward the reform of procedural mechanisms. As this most recent burst of prosecutorial activity comes to an end, the world might well reflect, as it did after Nuremberg and Tokyo, on how it could improve the way it brings genocidaires and war criminals to justice.

457 Dubinsky, supra note 369, at 213.

458 Id.

459 See Chernor Jalloh \& Alhogi Marong, Ending Impunity: The Case for War Crimes Trials in Liberia, 1 AFR. J. LEGAL STUD. 53, 75 (2005) (noting the international community's dissatisfaction with relatively limited results after lavish spending on the ad hoc Tribunals and concluding: "With respect to the possibility of an independent nationalized tribunal for Liberia, that would appear highly unlikely in view of the political difficulties cited above, tribunal fatigue at the Security Council, including the paucity of resources for existing tribunals such as the Special Court [for Sierra Leone], the need for resources for the pending Cambodia tribunal, and a solidification of the ICC (which is not fully yet established internationally).").

460 See id. 
What might this entail? It would be tempting just to politically cherry-pick due process features from national jurisdictions, currently lacking at the ad hoc Tribunals and the ICC, and simply graft them onto the international mold. But that would not be realistic. The limiting forces analyzed in this Article, while not necessarily intractable, cannot simply be ignored. Fragmentation will not go away overnight. Integration is a gradual metamorphosis. And gravity is immutable.

Professor Safferling might have laid out the most realistic road map. And to use it will require a paradigm shift. Instead of trying to model themselves on national systems, international criminal procedure will have to forge its own identity. "[T] he aim must be a truly international criminal procedure which should not be used as a test for the credibility of domestic penal systems, but stands solidly on the various traditions of criminal procedure."

To perceive fragmentation, integration, and gravity as insurmountable obstacles to the achievement of this goal may be unduly pessimistic. The twentieth century saw the birth of the United Nations, an international police force (Interpol), and political, military and economic regional integration on an unprecedented scale. ${ }^{462}$ If the twenty-first century is to replicate the pace of these unifying trends, uniform law enforcement procedure across national frontiers, and with it the gradual demise of fragmentation, may not be that far off. According to Professor Dianne Marie Amann, that part of the paradigm shift is well under way:

Traditionally, how a state chose to fight crime was an internal matter. States developed their own methods to investigate crimes, to capture and try suspects, and to punish criminals. That changed in the last half-century. Crime became global, spurring law enforcement officers in

\footnotetext{
461 Safferling, supra note 12 , at 2.

462 See James E. Hickey, Jr., The Source of International Legal Personality in the 21st Century, 2 HOFSTRA L. \& POL'Y SYMP. 1, 2 (1997) ([T]he early 1990s also signaled the end of the Cold War and an accelerating movement toward global economic integration and political cooperation on regional and global fronts. . . the global problems needing global responses have increased dramatically in the last half decade in such areas as crime, energy, the environment, finance, food, human rights, intellectual property, natural resources, and trade, all of which have involved varying degrees of international effort to resolve . . . the number of entities, state and non state, that have become involved in those global issues has multiplied exponentially and now collectively number in the thousands); Michael J. Graetz, The David R. Tillinghast Lecture Taxing International Income: Inadequate Principles, Outdated Concepts, and Unsatisfactory Policies, 54 TAX L. REV. 261, 269 (2001) ("Recent changes in the world economy--the unprecedented movement of goods and services and of labor and capital throughout the world, the innovations in financial instruments and business combinations, the economic and political unification of Europe, the emergence of capitalism in the former Soviet Union and eastern Europe and of China as a major economic force, the advent of electronic commerce, and ongoing integration of the world's economy--demand a thoroughgoing review."); Arthur A. Baer, Latino Human Rights and the Global Economic Order, 18 CHICANO-LATINO L. REV. 80, 81-82 (1996) ("The world is moving toward global economic integration as a result of a number of factors, including the accelerated movement of capital (facilitated by increased speed of information and transfers of wealth), reduced political constraints, the accelerated movement of people, and the political and economic disintegration of the bipolar world.").
} 
individual states to join together in an international attack on crime. ${ }^{463}$

Similarly, a Procrustean melding of the civil and common law traditions will not nullify integration as a limiting force. ${ }^{464}$ Instead, with due process as its policy lodestar, international criminal procedure must judiciously mix and match the best features that each system has to offer. ${ }^{465}$

The jury trial right comes to mind here. Perhaps the solution is not simply to impose the Anglo-American jury procedure wholesale onto the international criminal trial template. Instead, a mixed panel of professional judges and lay jurors could be used. The Continental system avails itself of this procedure for limited crimes. ${ }^{466}$ The ICC could use it for all trials. This might ease the logistical burden by limiting the requisite size of jury pools. At the same time, it would go far toward insulating the fact-finders from perceptions of ignorance and bias, on one hand, and extreme intellectual detachment on the other.

Defense access to evidence might be treated in a similar manner. In the international setting, a predominately adversarial model invests the prosecution with a significant resource advantage over the defense and provides institutional channels of communication with governments, typically not available to the defense, that significantly facilitate collection of evidence. ${ }^{467}$ On the other hand, reliance on the inquisitorial model, which designates a juge d'instruction to conduct investigations, could result in relatively lackadaisical inquiries. ${ }^{468}$ A hybrid procedure might employ a specially designated pre-trial judge to participate in or oversee the collection of evidence. This would promote "equality of arms" by helping to facilitate defense collection of evidence abroad and insure prosecutorial disclosure of exculpatory evidence. The ICC system, seeking to expand defendants' due process rights, already involves a certain degree of judicial pre-trial oversight of the prosecutor. A hybrid system extending that oversight to the collection of evidence would further level the playing field while preserving the inherent assiduousness of prosecutorial investigation.

\footnotetext{
463 Dianne Marie Amann, Harmonic Convergence? Constitutional Criminal Procedure in an International Context, 75 IND. L. J. 809, 810 (2000).

464 See Bassiouni, supra note 6 at 407 n. 64 ("[I]nternational prosecutions require sui generis rules and . . . domestic legal experiences may not be relevant to such processes.").

465 See Safferling, supra note 12, at 2 ("In this the two traditions have an overlapping goal: to actualize fundamental human rights within a fair procedure. Alongside this common objective, the differences could even be understood as being in a sort of competition: which system is capable of better protecting the rights of the offender; which system provides for a greater possibility of balancing the different rights and interests that are at stake? Starting from an international human rights perspective one has to compare carefully both approaches and contemplate how they try to safeguard the individual rights in each stage of the procedure.").

466 See Pizzi \& Montagna, supra note 447, at 433-34.

467 See Bassiouni, supra note 6, at 589.

468 See Ellen E. Sward, Values, Ideology, and the Evolution of the Adversary System, 64 IND. L. J. 301, 312 (1989).
} 
In the end, reform through further hybridization, as opposed to political concession, will create a distinctively unique institution, less torn by allegiance to one or the other system and more responsive to the special needs of transnational criminal practice. ${ }^{469}$ Professor Bassiouni believes that this process of hybridization, reflected in the evolution of an underlying adversarial model in both national and international settings, is already well under way:

Contemporaneously, another process of harmonization, or at least of rapprochement in the standards of "due process" developed at the national levels as evidenced by the laws and jurisprudence of the world's criminal justice systems and by the judges who interpret and command respect for the norms shared by various states. The convergence of these developments gave rise to general principles of law on the subject of "international due process" which the ICTY, ICTR and ICC have recognized and applied in their statutes and in the respective jurisprudence of the ICTY and ICTR. ${ }^{470}$

Finally, although the perception of genocide and war crimes may never change, the way that perception affects their prosecution might. In this age of the Internet and the global village, the world community may eventually become inured to prosecuting crimes that are monstrous on a world scale.

In the United States, for example, first-degree murderers get a fair shake at every stage of criminal proceedings. ${ }^{471}$ If anything, in capital cases the system bends over backwards to extend every due process consideration possible. ${ }^{472}$ This happens not because society is any less revolted by the sheer evil of such crimes. It happens because, over time, institutional lynch-mob passions abate and society is allowed to appreciate the oft-stated maxim that it is better for ten people to go free than for one innocent person to go to prison. ${ }^{473}$ Anesthetizing the world to the process of handling genocide may instill it with the same appreciation.

469 See Dubinsky, supra note 369, at 311(noting that the creation of an international tribunal has "fostered a useful hybridization of procedural law that is more difficult to create in national legal systems.").

470 Bassiouni, supra note 6, at 587.

471 See Mark Schlesinger, Inside Each Black Box of Health Policy: An Exciting Surprise!, 29 J. HEALTH POL. POL'Y \& L. 1035, 1037 (2004).

472 See W. Noel Keyes, The Choice of Participation by Physicians in Capital Punishment, 22 WHITTIER L. REV. 809, 820 (2001) (referring to the "super due process" imposed by the U.S. Supreme Court in all capital cases).

473 This saw is often attributed to either William Blackstone or Matthew Hale. See, e.g., Harold J. Berman \& Charles J. Reid, Jr., The Transformation of English Legal Science: From Hale to Blackstone, 45 EMORY L.J. 437, 482 (1996). See also In re Winship, 397 U.S. 358, 372 (1970) (stating the "fundamental value determination of our society that it is far worse to convict and innocent man than to let a guilty man go free."). 
And proactive efforts to educate the public about the importance of due process in mass atrocity prosecution ought to hasten this process. To some extent, prosecution and legal reform already help serve this role. ${ }^{474}$ As noted by Shelby Quast, the Director General of the International Legal Assistance Consortium: "In the international legal community, we hope we can learn a little more each time we are called to assist a postconflict society in addressing rule of law and begin to build an evolving catalog of best practices to be implemented in the field." ${ }^{475}$ But such efforts must also include assiduous educational programs. Quast concludes that:

Even the best laws cannot make a difference if they cannot be implemented. Law reform must often be accompanied by education that addresses the needs of society to understand, adopt, and implement such reforms. ${ }^{476}$

Of course, any such reform through education must be directed not only to victim societies, but to society at large. For the latter will help investigate the crimes, apprehend the suspects, furnish the administrative and human resources, and dispense the justice. The international community must be wary, however, that any such outreach efforts result in callous attitudes toward mass atrocity. Instead, any such program should seek to instill sensitization through promotion of human rights values at every stage of social and legal transition. In the prescient words of Justice Murphy dissenting fifty years ago in the Yamashita case $^{477}$ :

The immutable rights of the individual . . belong not alone to the members of those nations that excel on the battlefield or that subscribe to the democratic ideology. They belong to every person in the world, victor or vanquished, whatever may be his race, color, or beliefs . . . No exception is made as to those who are accused of war crimes or as to those who possess the status of enemy belligerent. Indeed, such an exception would be contrary to the whole philosophy of human rights. . . ${ }^{478}$

An uncurbed spirit of revenge and retribution, masked in formal legal procedure for purposes of dealing with a fallen enemy commander, can do more lasting harm than all of the atrocities giving rise to that spirit. The people's faith in the fairness and objectiveness of the law can be seriously undercut by that spirit. ${ }^{479}$

474 See Kritz, supra note 3, at 147.

475 Shelby Quast, Rule of Law in Post-Conflict Societies: What Is the Role of the International Community?, 39 NEW ENG. L. REV. 45 (2004).

476 Id. at 47.

477 In re Yamashita, 327 U.S. 1 (1946). Japanese General Yamashita, who served as commander of Japanese forces in the Philippines in the last month of the Japanese occupation, was held to a strict liability standard of command responsibility. In other words, he was found guilty of war crimes committed by the troops under his command even though he had no actual or constructive knowledge that crimes were being committed. That standard has been rejected. See Curt A. Hessler, Note, Command Responsibility for War Crimes, 82 YAlE L.J. 1274, 1276-77 (1973); Greg R. Vetter, Command Responsibility of Non-Military Superiors in the International Criminal Court, 25 YALE J. INT'L L. 89, 134 (2000).

478 Id. at 26.

479 Id. at 41 . 